\title{
Reductive dechlorination in recalcitrant sources of chloroethenes in the transition zone between aquifers and aquitards
}

Diana Puigserver 1

Phone +34-93-4021399

Email puigserverdiana@ub.edu

Jofre Herrero 1

Phone +34-93-4021417

Email jofreherreroferran@ub.edu

Mònica Torres 1

Phone +34-93-4021417

Email monicatorres@ub.edu

Amparo Cortés 2

Phone +34-93-4024494

Email acortes@ub.edu

Ivonne Nijenhuis 3

Phone + 49-341-2351356

Email ivonne.nijenhuis@ufz.de

Kevin Kuntze 3

Phone +49-341-2351356

Email kevin.kuntze@ufz.de

Beth L. Parker 4

Phone +1-519-8244120

Email bparker@uoguelph.ca

José M. Carmona 1,*

Phone +34-93-4021399

Emailjmcarmona@ub.edu 
Department de Gequímica, Petrologia i Prospecció Geològica, Facultat de Geologia, Universitat de Barcelona, C/ Martí i Franquès, s/n, 08028 Barcelona, Spain

2 Departament de Productes Naturals, Biologia Vegetal i Edafologia, Facultat de Farmàcia, Universitat de Barcelona, Av. Joan XXIII, s/n., 08028 Barcelona, Spain

3 Department of Isotope Biogeochemistry, Helmholtz Centre for Environmental Research (UFZ), Permoserstrasse 15., 04318 Leipzig, Germany

${ }^{4}$ School of Engineering, University of Guelph, 50, Stone Road East, Guelph, ON, N1G 2W1 Canada

\section{Abstract}

In the transition zone between aquifers and basal aquitards, the perchloroethene pools at an early time in their evolution are more recalcitrant than those elsewhere in the aquifer. The aim of this study is to demonstrate that the biodegradation of chloroethenes from aged pools (i.e., pools after decades of continuous groundwater flushing and dissolution) of perchloroethene is favored in the transition zone. A field site was selected where an aged pool exists at the bottom of a transition zone. Two boreholes were drilled to obtain sediment and groundwater samples to perform chemical, isotopic, molecular, and clone library analyses and microcosm experiments. The main results were as follows: (i) the transition zone is characterized by a high microbial richness; (ii) reductively dechlorinating microorganisms are present and partial reductive dechlorination coexists with denitrification, Fe and $\mathrm{Mn}$ reduction, and sulfate reduction; (iii) reductively dechlorinating microorganisms were also present in the zone of the aged pool; (v) the high concentrations of perchloroethene in this zone resulted in a decrease in microbial richness; (vi) however, the presence of fermenting microorganisms supplying electrons for the reductively dechlorinating microorganisms prevented the reductive dechlorination to be inhibited. These findings suggest that biostimulation and/or bioaugmentation could be applied to promote complete reductive dechlorination and to enhance the dissolution of more nonaqueous phase liquids (DNAPL).

\section{Keywords}

Aged PCE pool 
Transition zone to a basal aquitard

Biotic reductive dechlorination

Biodegradation halo

Richness of microbial communities

Genus Dehalococcoides

Responsible editor: Robert Duran

Electronic supplementary material

The online version of this article (doi: 10.1007/s11356-016-7068-4 ) contains supplementary material, which is available to authorized users.

\section{Introduction}

Chloroethenes are chlorinated solvents that belong to the group of nonaqueous phase liquids (DNAPL) and have been involved in numerous contamination episodes. Mackay et al. (2006) compiled their chemical and physical properties. The latter facilitate its migration as free phase through the subsurface (Mercer and Cohen 1990; Parker et al. 2003 ). Furthermore, the dissolved contaminant can penetrate low-conductivity materials by molecular diffusion (Parker et al. 1994; Chapman and Parker 2005; Sale et al. 2008). This process hinders the remediation of the aquifer because of slow back diffusion of the compounds from the low-conductivity material (Chapman and Parker 2005; Parker et al. 2008; Chapman et al. 2012).

The transition zones between granular aquifers and basal aquitards were described by Parker et al. (2003) as a reasonable paradigm for the DNAPL source area architecture in granular aquifers. Such zones are located at the bottom of many aquifers and are characterized by the presence of numerous thin silty-clay layers interstratified with coarser-grained layers (i.e., sands and gravels), which results in a considerable heterogeneity. Furthermore, retardation factors and contaminant concentrations, in the case of aged sources, are higher in the fine-grained layers (less conductive) than in the adjacent coarser-grained layers (Rivett et al. 2014). An aged pool is a former pool of free phase, which is currently an ancient pool where the DNAPL partially occupies the pores at saturations below the residual saturation value (Hartog et al. 2010) and constitutes an immobile phase retained by capillary forces. In addition, the groundwater flow is very slow in the transition zones because the hydraulic conductivity is lower than in the shallower part of the aquifer. For this reason, DNAPL is dissolved and flushed away from the more conductive zones of the aquifer after decades of groundwater flow when the source is aged, whereas DNAPL concentrations may remain close to or at solubility in the transition 
zones (Parker et al. 2003). This low contaminant mobility in transition zones should be pointed out since it implies that DNAPL sources in these zones are recalcitrant (much more than those in the rest of the aquifer), which has far reaching implications for the environment. Puigserver et al. (2013)

demonstrated that numerous biogeochemical processes coexisted in the transition zone to a basal aquitard at a particular site in La Pineda (Camp de Tarragona, NE Spain). In this site, the aquifer was contaminated by chlorinated solvents (chloroform and carbon tetrachloride), and it was situated in a geological context of distal prograding alluvial fan deposits (sheet floods) formed by sand layers and interbedded silts rich in organic matter and with a large diversity of microorganisms. In the transition zone of this aquifer, layers with fine-grained materials showed greater microbial richness than layers of coarser-grained materials. Groundwater flow through the more conductive layers supplied nutrients, contaminants, and electron donors, which led to the biodegradation of dissolved chlorinated solvents.

Chloroethenes may be recalcitrant under some conditions over long periods (several decades or longer). However, they can also be biodegraded, for example, under anoxic conditions by biotic reductive dechlorination (Wiedemeier et al. 1998; Bradley 2003 and 2011), which is carried out by organohalide-respiring bacteria (OHRB). Moreover, some studies show that the presence of dechlorinating activity can significantly enhance the dissolution rate of the source of perchloroethene (PCE) (Yang and McCarty 2000, 2002). Reductive dechlorination of chloroethenes takes place by sequential dechlorination from PCE to trichloroethene (TCE), to 1,2-cis-dichloroethene (cDCE), which is the most common metabolite in TCE biodegradation (Bouwer 1994), to vinyl chloride (VC), and to ethene or ethane (Vogel et al. 1987; Tiehm and Schmidt 2011). Reductive dechlorination of PCE and TCE may take place under nitrate- (van der Zaan et al. 2010), Mn-, and Fe-reducing conditions (Bradley and Chapelle 2011), under sulfate-reducing and methanogenic conditions (Bouwer 1994; Chapelle 1996; Bradley 2003), especially if an excess of electron donors is supplied to achieve substantial dechlorination (Aulenta et al. 2007). The reductive dechlorinating sequence may be wholly or partially inhibited by the competition for electron donors depending on the environmental conditions. This competition is between communities of OHRB and communities of anaerobic hydrogenotrophic (including reducers of $\mathrm{NO}_{3}{ }^{-}$, $\mathrm{Mn}^{4+}, \mathrm{Fe}^{3},{ }^{+}$and $\mathrm{SO}_{4}{ }^{2-}$ ), autotrophic methanogenic, and homoacetogenic microorganisms (Wei and Finneran 2011). Among the microorganisms capable of reductively dechlorinating chloroethenes are the genera Desulfitobacterium, Clostridium, and those related to Dehalobacter restrictus (Miller et al. 1996; Kim et al. 2006). Dehalococcoides mccartyi strain 195 is the most widely 
studied strain that dechlorinates PCE to ethene, whereas other OHRB are not usually able to dechlorinate PCE past $\mathrm{CDCE}$ and result in an accumulation of metabolites that are more toxic than PCE in the aquifer (Maymó-Gatell et al. 1997; Sung et al. 2003; Yoshida et al. 2007). Oxidizing microorganisms have also been identified, such as aerobes, which are able to oxidize chloroethenes to $\mathrm{CO}_{2}$ (Verce et al. 2002). High concentrations of chloroethenes in the source may inhibit microbial activity (National Research Council 1999), causing a decrease in the microbial richness of the population due to their toxicity (Haack and Bekins 2000).

Although Puigserver et al. (2013) demonstrated that numerous biogeochemical processes coexisted in the transition zone in the plume, a review of the literature reveals a significant gap in knowledge concerning the biogeochemical processes that take place in transition zones in which DNAPL sources are found. The present study aims to fill this gap by analyzing the reductive dechlorination occurring in this transition zone in a source area and to study how it is affected by other biogeochemical processes. To this end, a working hypothesis was formulated: the reductive dechlorination of chloroethenes in these transition zones occurs despite the potential inhibition that arises as a result of microbial competition and the partial inhibition of microbial communities caused by the high concentrations of PCE. To test this hypothesis, a field site on a confined aquifer consisting of Pliocene prograding alluvial fan deposits was selected in an industrial area in Vilafant (Alt Empordà, NE Spain), approximately $150 \mathrm{~km}$ to the north of Barcelona. A transition zone to a basal aquitard exists at the lower section of the aquifer between the depths of 5.60 and $7.50 \mathrm{~m}$, where a PCEDNAPL source was detected by the Catalan Water Agency (ACA).

\section{Site description}

\section{History of the site}

The site consists of a confined aquifer made up of Pliocene materials.

Chloroethene contamination was detected at the site in 1980, but it is not known when this originated. The main contaminant is PCE, which was used as a degreaser of vehicle parts at a nearby industrial plant serving the automotive industry. PCE as DNAPL was most likely dumped into an old abandoned agricultural well located in the plant. Groundwater contamination resulted in concentrations of PCE that remained high in 2012, the maximum value being $104 \mu \mathrm{mol} / \mathrm{L}$ (i.e., $17,300 \mu \mathrm{g} / \mathrm{L}$ ), whereas TCE and cDCE were 0.30 and $0.26 \mu \mathrm{mol} / \mathrm{L}$, respectively (i.e., 39 and $25 \mu \mathrm{g} / \mathrm{L}$, respectively). Except for monitoring natural attenuation, other remediation measures have not been implemented by the ACA. 
The monitoring network consists of 12 conventional wells installed by the ACA. In addition, two boreholes (B-F1UB and B-F2UB) were drilled by our research group in January 2011 and were subsequently equipped as multilevel wells (F1UB and F2UB in Fig. 1; the construction characteristics of these wells are given in Table 1 ).

\section{Fig. 1}

Monitoring network of the site. PCE concentrations in the plume (2011) in micromole per liter. Piezometric map (2011) in meters above sea level. Black arrow indicates groundwater flow direction

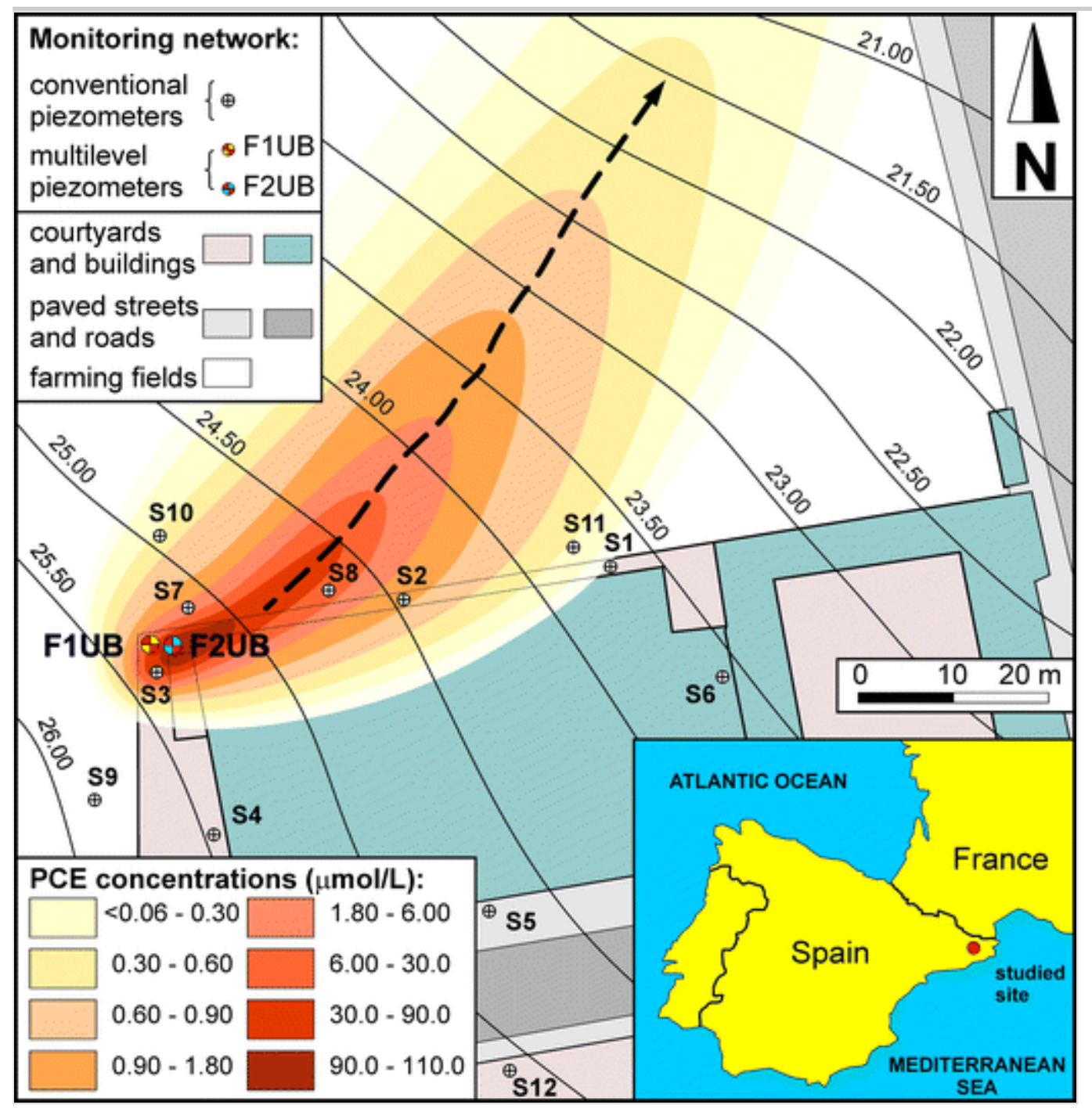

\section{Table 1}

Construction characteristics of multilevel wells

F1UB

\begin{tabular}{l|l|l|l|l}
$\begin{array}{l}\text { Number } \\
\text { of port }\end{array}$ & $\begin{array}{l}\text { Screening } \\
\text { length }(\mathrm{m})\end{array}$ & $\begin{array}{l}\text { Port } \\
\text { depth } \\
(\mathrm{m})\end{array}$ & Range of depths $(\mathrm{m})$ & $\begin{array}{l}\text { Length of sections } \\
(\mathrm{m})\end{array}$
\end{tabular}

Sections filled with bentonite and quartz sand (3 mm grain size)

(m) 


\begin{tabular}{|c|c|c|c|c|c|}
\hline & $\begin{array}{l}\text { Cement } \\
\text { grout }\end{array}$ & $\begin{array}{l}0.00- \\
2.50\end{array}$ & 2.50 \\
\hline & & & Bentonite & $\begin{array}{l}2.50- \\
4.96\end{array}$ & 2.46 \\
\hline \multirow[t]{2}{*}{3} & 0.06 & 5.06 & $\begin{array}{l}\text { Quartz } \\
\text { sand }\end{array}$ & $\begin{array}{l}4.96- \\
5.17\end{array}$ & 0.21 \\
\hline & & & Bentonite & $\begin{array}{l}5.17- \\
5.40\end{array}$ & 0.23 \\
\hline \multirow[t]{2}{*}{4} & 0.06 & 5.51 & $\begin{array}{l}\text { Quartz } \\
\text { sand }\end{array}$ & $\begin{array}{l}5.40- \\
5.63\end{array}$ & 0.23 \\
\hline & & & Bentonite & $\begin{array}{l}5.63- \\
5.82\end{array}$ & 0.19 \\
\hline \multirow[t]{2}{*}{5} & 0.06 & 5.96 & $\begin{array}{l}\text { Quartz } \\
\text { sand }\end{array}$ & $\begin{array}{l}5.82- \\
6.05\end{array}$ & 0.23 \\
\hline & & & Bentonite & $\begin{array}{l}6.05- \\
6.26\end{array}$ & 0.21 \\
\hline \multirow[t]{2}{*}{6} & 0.06 & 6.33 & $\begin{array}{l}\text { Quartz } \\
\text { sand }\end{array}$ & $\begin{array}{l}6.26- \\
6.51\end{array}$ & 0.25 \\
\hline & & & Bentonite & $\begin{array}{l}6.51- \\
6.79\end{array}$ & 0.28 \\
\hline \multirow[t]{2}{*}{7} & 0.06 & 6.91 & $\begin{array}{l}\text { Quartz } \\
\text { sand }\end{array}$ & $\begin{array}{l}6.79- \\
7.14\end{array}$ & 0.35 \\
\hline & & & Bentonite & $\begin{array}{l}7.14- \\
17.00\end{array}$ & 9.86 \\
\hline \multicolumn{3}{|c|}{ F2UB } & \multicolumn{3}{|c|}{$\begin{array}{l}\text { Sections filled with bentonite and quartz } \\
\text { sand ( } 3 \mathrm{~mm} \text { grain size) }\end{array}$} \\
\hline & $\begin{array}{l}\text { Screening } \\
\text { length }(\mathrm{m})\end{array}$ & $\begin{array}{l}\text { Port } \\
\text { depth } \\
\text { (m) }\end{array}$ & \multicolumn{2}{|c|}{ Range of depths (m) } & $\begin{array}{l}\text { Length of sections } \\
(\mathrm{m})\end{array}$ \\
\hline \multirow[b]{3}{*}{3} & & & $\begin{array}{l}\text { Cement } \\
\text { grout }\end{array}$ & $\begin{array}{l}0.00- \\
2.50\end{array}$ & 2.50 \\
\hline & & & Bentonite & $\begin{array}{l}2.50- \\
5.27\end{array}$ & 2.77 \\
\hline & 0.06 & 5.37 & $\begin{array}{l}\text { Quartz } \\
\text { sand }\end{array}$ & $\begin{array}{l}5.27- \\
5.49\end{array}$ & 0.22 \\
\hline \multirow[b]{2}{*}{4} & & & Bentonite & $\begin{array}{l}5.49- \\
5.63\end{array}$ & 0.14 \\
\hline & 0.06 & 5.67 & $\begin{array}{l}\text { Quartz } \\
\text { sand }\end{array}$ & $\begin{array}{l}5.63- \\
5.82\end{array}$ & 0.19 \\
\hline & & & Bentonite & $\begin{array}{l}5.82- \\
6.12\end{array}$ & 0.3 \\
\hline 5 & 0.06 & 6.18 & $\begin{array}{l}\text { Quartz } \\
\text { sand }\end{array}$ & $\begin{array}{l}6.12- \\
6.33\end{array}$ & 0.21 \\
\hline
\end{tabular}




\begin{tabular}{|l|l|l|l|l|l|}
\hline \multicolumn{2}{|c|}{} & & Bentonite & $\begin{array}{l}6.33- \\
6.59\end{array}$ & 0.26 \\
\hline 6 & \multirow{2}{*}{0.06} & 6.66 & $\begin{array}{l}\text { Quartz } \\
\text { sand }\end{array}$ & $\begin{array}{l}6.59- \\
6.81\end{array}$ & 0.22 \\
\hline & & & Bentonite & $\begin{array}{l}6.81- \\
7.12\end{array}$ & 0.31 \\
\hline 7 & \multirow{2}{*}{0.06} & \multirow{2}{*}{7.2} & $\begin{array}{l}\text { Quartz } \\
\text { sand }\end{array}$ & $\begin{array}{l}7.12- \\
7.34\end{array}$ & 0.22 \\
\hline & & & Bentonite & $\begin{array}{l}7.34- \\
20.20\end{array}$ & 12.86 \\
\hline
\end{tabular}

\section{Geological and hydrogeological framework}

The Pliocene prograding alluvial fan deposits, which belong to the geological context of the Pyrenees range and that constitute the subsurface materials at the site (IGME 1994; IGC 1996), are divided into three lithological units. The upper unit of the sequence is dominated by proximal deposits of gravels and sands that are mostly channelized and display high porosity despite the presence of some isolated discontinuous intervals of clays and sands. The middle unit consists of deposits of distal alluvial fans (sheet floods) made up of sand layers and interbedded silts that are rich in organic matter. The lower unit of the sequence corresponds to basin plain deposits that are mainly composed of fine sands and silts. Multilevel wells F1UB and F2UB and other conventional wells of the monitoring network reach the depth at which this lithological unit is located. The stratigraphic correlation of borehole logs showed that these units dip toward the northeast.

The aquifer is composed of two sections: (i) a part of the proximal coarsegrained alluvial fan deposits (upper unit) in which hydraulic conductivities range from 10 to $20 \mathrm{~m}$ /day and (ii) the distal alluvial fan deposits (middle unit), whose hydraulic conductivities range between 1 and $10 \mathrm{~m} /$ day. Gravel paleochannels of the distal alluvial fan deposits act as drainage lines, coinciding with the general flow toward the northeast as shown in Fig. 1. The average annual fluctuation of the piezometric level is $1.50 \mathrm{~m}$, and the average horizontal hydraulic gradient is 0.020 . Groundwater flow velocities range between 0.20 and $0.41 \mathrm{~m} /$ day in the upper unit and between 0.02 and $0.20 \mathrm{~m}$ /day in the middle unit. The fine sands and silts of the lowermost lithological unit constitute an aquitard.

\section{Hydrostratigraphic units differentiated in the subsurface}

Five hydrostratigraphic units of Pliocene age were differentiated from surface to bottom (Fig. 2): (1) the unsaturated zone, which is made up of gravels and 
coarse, medium and fine sands; (2) the upper aquitard (upper discontinuous thin aquitard), which mostly consisted of clays and was crossed by subvertical microfractures; (3) the upper part of the aquifer was mainly constituted by gravels; and (4) the lower part of the aquifer, which comprised the transition zone to the basal aquitard, was made up of alternating gravels and coarse sands with numerous interbedded layers of medium to fine sands and silts at the centimeter to decimeter scale. The number of lithological and textural changes in this unit was among the highest in the geological profile (Table 2(A)). A stratigraphic correlation with cores of conventional piezometers of the monitoring network showed that these layers had a limited lateral extension. (5) Lastly, the basal aquitard consisted of fine laminar sands and silts crossed by a dense network of subvertical microfractures.

\section{Fig. 2}

Geological profile of the boreholes B-F1UB (a) and B-F2UB (b). Hydrostratigraphic units differentiated are included. The vertical scales expressed in meters below ground surface. $S Z$ saturated zone. USZ unsaturated zone, UDTA upper aquitard (upper discontinuous thin aquitard), UPA upper part of the aquifer, TZBA transition zone (transition zone to the basal aquitard, i.e., the lower part of the aquifer), $B A$ basal aquitard, UPBA upper part of the BA, $L P B A$ lower part of the BA. Lithological and textural descriptions: B-F1UB: USZ $(0.00-3.30 \mathrm{~m})$ : alternating gravels and medium to fine sands (gravels with no matrix and sands with a high silty-clayey matrix content). UDTA $(3.30-4.37 \mathrm{~m})$ : greenish clays with interbedded fine and medium sands (a network of vertical microfractures intersects these materials). UPA (4.37-5.88 m): poorly sorted gravels and small proportion of coarse and medium sands (gravels and sands with a very little matrix content). Very few interbedded layers of silts. TZBA $(5.88-7.50 \mathrm{~m})$ : alternating coarse to fine sands with numerous interbedded layers of silts (sands with very high content of silty-clayey matrix, especially when closer to the contact with the BA). BA $(7.50-17.00 \mathrm{~m})$ : very fine sands and, in much lesser proportion, silts (all these materials are affected by vertical microfractures). B-F2UB: USZ (0.00-3.58): alternating medium sands with interbedded gravel and coarse sand layers (gravels and sands with higher silty-clayey matrix content than in B-F1UB). UDTA (3.58$4.18 \mathrm{~m}$ ): greenish clays (intersected by vertical microfractures). UPA (4.18$5.60 \mathrm{~m}$ ): alternating gravels and medium to fine sands (similar content of siltyclayey matrix in gravels and sands than in the case of B-F1UB). Very few interbedded layers of silts. TZBA $(5.60-7.40 \mathrm{~m})$ : gravels and coarse sands with interbedded layers of medium to fine sands (gravels with no matrix and sands with lower silty-clayey matrix content than in B-F1UB). BA (7.40-20.20 m): very fine sands with silty matrix (affected by vertical microfractures). Thin interbedded layers of medium sands to fine gravels 


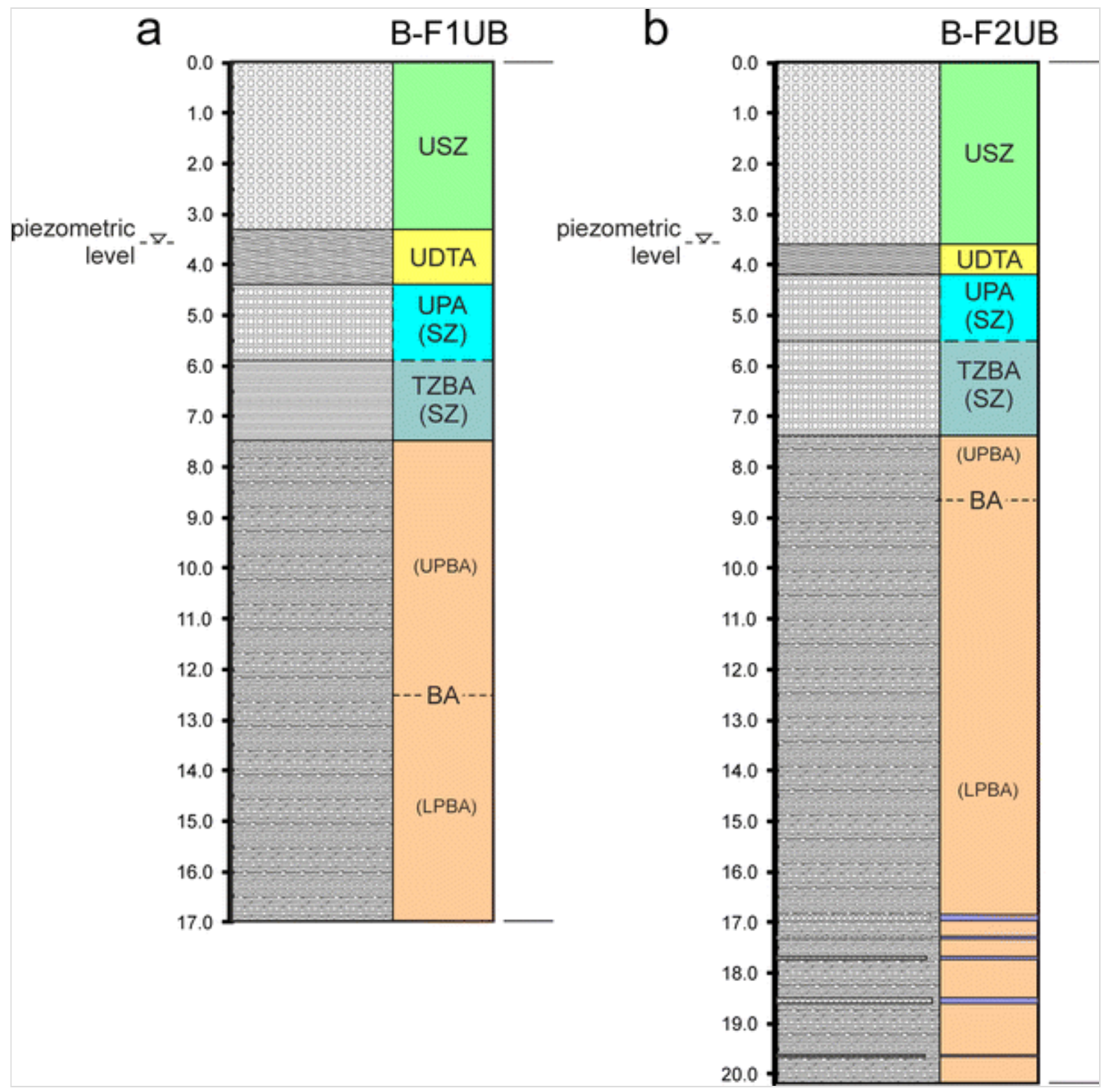

\section{Table 2}

Textural characteristics of sediments in each of the hydrostratigraphic units distinguished in B-F1UB and B-F2UB: (A) number of textural and lithological changes per meter of thickness of each hydrostratigraphic unit (range of depth in brackets), (B) total thickness (in meters) of layers of the different types of sediment in each hydrostratigraphic unit (grain size in brackets), and (C) percentage of matrix in gravel and sand layers of the USZ, UPA, and TZBA units

\begin{tabular}{|c|c|c|c|c|c|}
\hline A & \multicolumn{3}{|c|}{ B-F1UB } & \multicolumn{2}{|c|}{ B-F2UB } \\
\hline USZ & 6.41 & \multicolumn{2}{|c|}{$(0.00-3.30 \mathrm{~m})$} & 10.05 & $(0.00-3.58 \mathrm{~m})$ \\
\hline UDTA & 3.50 & \multicolumn{2}{|c|}{$(3.30-4.37 \mathrm{~m})$} & 1.42 & $(3.58-4.18 \mathrm{~m})$ \\
\hline UPA (SZ) & 2.31 & \multicolumn{2}{|c|}{$(4.37-5.88 \mathrm{~m})$} & 5.80 & $(4.18-5.60 \mathrm{~m})$ \\
\hline TZBA (SZ) & 6.74 & \multicolumn{2}{|c|}{$(5.88-7.50 \mathrm{~m})$} & 4.38 & $(5.60-7.40 \mathrm{~m})$ \\
\hline BA & 0.11 & \multicolumn{2}{|c|}{$(7.50-17.00 \mathrm{~m})$} & 0.47 & $(7.40-20.20 \mathrm{~m})$ \\
\hline & Gravels & Coarse & Medium & Fine & Clas \\
\hline
\end{tabular}




\begin{tabular}{|c|c|c|c|c|c|c|c|}
\hline B & & $\begin{array}{l}(2- \\
32 \mathrm{~mm})\end{array}$ & $\begin{array}{l}\text { sands } \\
(0.5- \\
2 \mathrm{~mm})\end{array}$ & $\begin{array}{l}\text { sands } \\
(0.25- \\
0.5 \mathrm{~mm})\end{array}$ & $\begin{array}{l}\text { sands } \\
(62.5- \\
250 \mu \mathrm{m})\end{array}$ & $\begin{array}{l}\text { Silts }(4- \\
62.5 \mu \mathrm{m})\end{array}$ & $\begin{array}{l}(1- \\
4 \mu \mathrm{m})\end{array}$ \\
\hline \multirow{5}{*}{$\begin{array}{l}\text { B- } \\
\text { F1UB }\end{array}$} & USZ & 1.28 & 0.12 & 0.77 & 0.97 & 0.15 & 0.01 \\
\hline & UDTA & 0.00 & 0.00 & 0.00 & 0.08 & 0.06 & 0.93 \\
\hline & $\begin{array}{l}\text { UPA } \\
(\mathrm{SZ})\end{array}$ & 1.44 & 0.01 & 0.02 & 0.00 & 0.04 & 0.00 \\
\hline & $\begin{array}{l}\text { TZBA } \\
(\mathrm{SZ})\end{array}$ & 0.05 & 0.14 & 0.63 & 0.67 & 0.13 & 0.00 \\
\hline & BA & 0.00 & 0.00 & 0.00 & 8.90 & 0.60 & 0.00 \\
\hline \multirow{5}{*}{$\begin{array}{l}\text { B- } \\
\text { F2UB }\end{array}$} & USZ & 0.88 & 0.63 & 1.43 & 0.29 & 0.00 & 0.35 \\
\hline & UDTA & 0.00 & 0.00 & 0.00 & 0.00 & 0.00 & 0.60 \\
\hline & $\begin{array}{l}\text { UPA } \\
(\mathrm{SZ})\end{array}$ & 1.17 & 0.00 & 0.07 & 0.15 & 0.03 & 0.00 \\
\hline & $\begin{array}{l}\text { TZBA } \\
(\mathrm{SZ})\end{array}$ & 0.72 & 0.68 & 0.26 & 0.14 & 0.00 & 0.00 \\
\hline & BA & 0.05 & 0.00 & 0.15 & 11.80 & 0.80 & 0.00 \\
\hline \multirow[t]{3}{*}{$\mathrm{C}$} & & \multicolumn{3}{|l|}{ B-F1UB } & \multicolumn{3}{|l|}{ B-F2UB } \\
\hline & & $\begin{array}{l}\text { Layers } \\
\text { with no } \\
\text { matrix }\end{array}$ & \multicolumn{2}{|c|}{$\begin{array}{l}\text { Layers with silty-clayey } \\
\text { to clayey matrix }\end{array}$} & $\begin{array}{l}\text { Layers } \\
\text { with no } \\
\text { matrix }\end{array}$ & \multicolumn{2}{|c|}{$\begin{array}{l}\text { Layers with } \\
\text { silty-clayey to } \\
\text { clayey matrix }\end{array}$} \\
\hline & & $(\%)$ & \multicolumn{2}{|l|}{$(\%)$} & $(\%)$ & \multicolumn{2}{|l|}{$(\%)$} \\
\hline \multirow{2}{*}{ USZ } & $\begin{array}{l}\text { Gravel } \\
\text { layers }\end{array}$ & 75.9 & \multicolumn{2}{|l|}{24.1} & 33.4 & \multicolumn{2}{|l|}{66.6} \\
\hline & $\begin{array}{l}\text { Sand } \\
\text { layers }\end{array}$ & 5.5 & \multicolumn{2}{|l|}{94.5} & 31.8 & \multicolumn{2}{|l|}{68.2} \\
\hline \multirow{2}{*}{$\begin{array}{l}\text { UPA } \\
(\mathrm{SZ})\end{array}$} & $\begin{array}{l}\text { Gravel } \\
\text { layers }\end{array}$ & 85.7 & \multicolumn{2}{|l|}{14.3} & 83.4 & \multicolumn{2}{|l|}{16.6} \\
\hline & $\begin{array}{l}\text { Sand } \\
\text { layers }\end{array}$ & 97.6 & \multicolumn{2}{|l|}{2.4} & 79.3 & \multicolumn{2}{|l|}{20.7} \\
\hline \multirow{2}{*}{$\begin{array}{l}\text { TZBA } \\
(\mathrm{SZ})\end{array}$} & $\begin{array}{l}\text { Gravel } \\
\text { layers }\end{array}$ & 0.5 & \multicolumn{2}{|l|}{95.0} & 96.9 & \multicolumn{2}{|l|}{3.1} \\
\hline & $\begin{array}{l}\text { Sand } \\
\text { layers }\end{array}$ & 15.3 & \multicolumn{2}{|l|}{84.7} & 32.3 & \multicolumn{2}{|l|}{67.7} \\
\hline
\end{tabular}


Borehole drilling, geological core description, and installation of multilevel wells

Boreholes B-F1UB and B-F2UB (17.00- and 20.20-m depth, respectively, and $2.50 \mathrm{~m}$ from each other) were drilled by rotary drilling with a diamond crown bit, which had a provisional metal sleeve casing with an external diameter of $127 \mathrm{~mm}$. A core sampler (85-mm internal diameter) was used to recover the cores (37.7-cm length on average). The geology of cores was described in detail at the site (Fig. 2), which allowed the differentiation of the coarser-grained layers from the finer layers, where a significant mass of chloroethenes tends to be stored. The drilling operations and the core sampler are described by Puigserver et al. (2013). The boreholes were equipped as multilevel wells (F1UB and F2UB, multi-level CMT-type 7 channels, Solinst) following the protocol established by Einarson and Cherry (2002) (see Table 1 for the construction characteristics of these multilevel wells). Of the seven ports of F1UB and F2UB, ports 1 and 2 were screened in the unsaturated zone. Port 7 in the multilevel well F1UB is at a depth of $6.91 \mathrm{~m}$ and is $7.20 \mathrm{~m}$ in F2UB (Table $1)$.

\section{Core sampling, analytical determinations in porewater, and sediment and screening for DNAPL}

In view of the considerable heterogeneity in the transition zone, intensive sampling of continuous cores from the two boreholes was essential to characterizing the presence of DNAPL, the vertical and lateral extent of DNAPL source, the distribution of DNAPL as residual or in pools, and the contaminant mass in porewater and sediments. Core sampling was also necessary: (1) to study the biogeochemical conditions under which the biodegradation processes occurred in the subsurface, (2) to analyze the depth variation of contaminants that resulted from degradation processes expressed as biodegradation haloes in the depth profile of concentrations (see "Reductive dechorination in the transition zone" section) and to verify the presence of microbial communities in sediment samples and to study their role in the degradation of chloroethenes.

Cores were exhaustively sampled in the field to characterize the vertical distribution of PCE, TCE, cDCE, trans-dichloroethene (tDCE), 1,1-DCE, and $\mathrm{VC}$ in porewater. All of these compounds were analyzed at each sampling depth, with 26 and 37 samples in B-F1UB and B-F2UB, respectively. The percentage of organic carbon $\left(f_{\text {oc }}\right)$ in sediments (26 and 32 samples in B-F1UB and B-F2UB, respectively), the total $\mathrm{Fe}$ and $\mathrm{Mn}$ sorbed in the fine fraction of sediments (12 and 32 samples, respectively), and the richness of microbial communities (see "Molecular analyses and clone library analyses" section) in these sediments (10 samples) were also analyzed. All samples for $f_{\text {oc }}, \mathrm{Fe}$, and Mn correspond to a 
sample of chloroethenes at the same depth. The distance between sampling points varied from 0.03 to $0.73 \mathrm{~m}(0.23 \mathrm{~m}$ on average) for chloroethenes, from 0.03 to $0.77 \mathrm{~m}(0.24 \mathrm{~m}$ on average $)$ for $f_{\text {oc }}$, from 0.07 to $1.02 \mathrm{~m}(0.32 \mathrm{~m}$ on average) for $\mathrm{Fe}$ and $\mathrm{Mn}$, and from 0.21 to $2.16 \mathrm{~m}$ ( $0.77 \mathrm{~m}$ on average) for richness of microbial communities. The sampling procedures are described in Puigserver et al. (2013). The sampling procedure and conservation protocol for chloroethene analysis, as well as the calculations of porewater concentrations were an adaptation of the protocol followed by Parker et al. (2003) and Chapman and Parker (2005) (see Electronic Supplementary Material for more details on sampling procedures, sampling criteria, and number of replicates and field, transport, reactant and instrumentation blanks, and conservation protocols, as well as for sample pretreatments and analytical techniques). Sudan IV screening for the colorimetric determination of residual DNAPL or free phase was conducted while drilling the two boreholes following the method described by Parker et al. (2003) and Hartog et al. (2010).

\section{AQ1}

AQ2

\section{Groundwater sampling and conservation protocols}

Groundwater chemistry in the transition zone where DNAPL was present also provided the chemical characterization of the dissolved phase contaminants at the depths of the source of contamination. Groundwater was sampled using multilevel wells. Their sampling ports, located at different depths, provided groundwater samples that offered a high-resolution image of the depth distribution of contaminants (Chapman et al. 2007). Changes in the concentrations of contaminants, oxidants, and metabolites were used to confirm the activity of different microorganisms and identify the processes involved. "In all cases, the sampling and conservation protocols reported by Puls and Barcelona (1996), Trevors (1996), Wiedemeier and Haas (2002), and Johnston (2006) were followed. Groundwater from ports 3 to 7 was sampled to analyze PCE; TCE; cDCE; $\mathrm{tDCE} 1,2$-trans-dichloroethene (tDCE); 1,1-DCE; VC; and the ${ }^{13} \mathrm{C}$ fractionation of chloroethenes, nitrate, nitrite, sulfate, $\mathrm{Fe}, \mathrm{Mn}$, and dissolved oxygen (DO) in the aquifer (See Electronic Supplementary Material for more details on groundwater sampling procedures, conservation protocols, sample pretreatments, and analytical techniques).

\section{Microcosm set-up and monitoring}

Two microcosm experiments were conducted. The first simulated the natural attenuation of PCE in the upper part of the aquifer, and the second simulated the natural attenuation of PCE in the transition zone to the basal aquitard. Each 
experiment consisted of two active tests (i.e., in which microorganisms were living) and two control tests (i.e., in which microorganisms were killed). Water samples from the two microcosm experiments were collected to study the time evolution of concentrations of the main inorganic electron acceptors $\left(\mathrm{SO}_{4}{ }^{2-}\right.$, $\mathrm{NO}_{3}{ }^{-}$, and $\mathrm{NO}_{2}{ }^{-}$), $\mathrm{PCE}, \mathrm{TCE}$, isomers of DCE, $\mathrm{VC}$, ethene, ethane, methane, $\mathrm{Mn}^{2+}$, and $\mathrm{Fe}^{2+}$ (determinations of $\delta^{13} \mathrm{C}$ values of chloroethenes or other organic compound in microcosm were not conducted). Sodium azide $\left(\mathrm{N}_{3} \mathrm{Na}\right.$ Fluka, purum pa) was added to the microcosm water samples immediately after being collected to inhibit bacterial activity. Before analysis, the vials containing the samples were stored in a cold chamber at $4{ }^{\circ} \mathrm{C}$ in total darkness. The temperature in the laboratory and inside the anaerobic chamber was maintained constant throughout the experiment $\left(16{ }^{\circ} \mathrm{C}\right.$, corresponding to the annual average temperature of the aquifer) (see Electronic Supplementary Material for more details on microcosm setup).

\section{Molecular analyses and clone library analyses}

Core samples were collected on site, were stored in sterilized vases, and were frozen on site. Molecular analyses were performed to verify the presence of microbial communities in sediment samples and to study their role in the degradation of chloroethenes. The richness of microbial communities was also assessed. This parameter refers to the number of different species in a community. The number of sediment samples was 21 for molecular analysis using the terminal restriction fragment length polymorphism (T-RFLP) technique and nested PCR, to identify Dehalococcoides (primer 582f, Duhamel et al. 2004; and primer 728r, Löffler et al. 2000), Geobacter (primers Geo73f and Geo485r; Duhamel and Edwards 2006), and Dehalobacter (primers Deb179f and Deb1007r; Schlötelburg et al. 2002), which are genus with well-known dechlorinating species. Replications were made (in duplicate) of each of the three restriction enzymes used. However, of the three assessed genus, only Dehalococcoides gave positive results since Dehalobacter and Geobacter were below the detection limit of the approach applied. As only Dehalococcoides spp. are known to be capable of the complete dehalogenation and detoxification of chloroethenes, this was one of the key groups of microorganisms to be considered. In addition, the clone libraries of two sediment samples taken in the transition zone were established. One of the samples originated at the depth where residual DNAPL was detected when drilling the boreholes (7.35 $\mathrm{m}$ deep) evidencing the presence of an aged pool (see "Reductive dechorination in the transition zone" section) and the other immediately above this pool $(6.90 \mathrm{~m}$ deep). The analyses were performed at the Helmholtz Centre for Environmental Research-UFZ (Leipzig, Germany). Genomic DNA was extracted from $1.10 \mathrm{~g}$ of sediment with NucleoSpin ${ }^{\circledR}$ Soil de Macherey \& Nagel following the 
manufacturer's protocol to perform the T-RFLP "and clone library analysis (see Electronic Supplementary Material for more details on molecular analyses and clone library analyses).

\section{Results and discussion}

\section{Biogeochemical processes in porewater and groundwater}

\section{Reductive dechorination in the upper part of the aquifer}

Pronounced peaks of PCE in porewater were located immediately below the contact upper aquitard-upper part of the aquifer at depths of $4.80 \mathrm{~m}$ $(6.94 \mu \mathrm{mol} / \mathrm{L})$ and $4.51 \mathrm{~m}(2.15 \mu \mathrm{mol} / \mathrm{L})$ for B-F1UB and B-F2UB, respectively (Fig. 3 a, labels $1 \mathrm{~A}_{3}$ and $2 \mathrm{~A}_{4}$ ). Although Sudan IV showed no signs of DNAPL currently present in the upper part of the aquifer, a fraction of the PCE-DNAPL that previously penetrated into the upper aquitard through the vertical microfractures would have reached these depths in the upper part of the aquifer and remained as residual DNAPL (i.e., as trails of immobile discontinuous DNAPL droplets or ganglia) trapped interstitially in the gravels and sands (in a similar manner to that described by Sale et al. 2008) of the top of this unit (Fig. 2 ), where groundwater conditions were oxidizing (DO concentration of $8.00 \mathrm{mg} / \mathrm{L}$ ) because of DO from the areas upgradient of the plant. Nitrification took place in F1UB (Fig. 4 a, port 3) owing to these oxidizing conditions, which are consistent with the low groundwater concentrations of TCE (0.010 and $0.011 \mu \mathrm{mol} / \mathrm{L}$ for the 2011 and 2012 surveys, respectively), suggesting a lower PCE degradation (with 2.06 and $0.48 \mu \mathrm{mol} / \mathrm{L}$ of PCE for the 2011 and 2012 surveys, respectively) than in the ports located in the transition zone (see "Reductive dechorination in the transition zone" section). The prevalence of the gravel and coarse sands in the upper part of the aquifer (Table 2(B)) and the lower percentage of layers with silty-clayey matrix (Table $2(\mathrm{C})$ ) give this unit a more homogeneous character and higher hydraulic conductivity than those of the upper and lower stratigraphic units. These explain why PCE-DNAPL pools did not accumulate and peaks of PCE did not form elsewhere in the upper part of the aquifer. A fraction of PCE residual DNAPL penetrated as dissolved phase into the fine matrix of sediments by molecular diffusion. Back diffusion from this matrix may cause the higher remnant groundwater concentrations in the upper part of the aquifer. Back diffusion from fine matrix also explains the lower groundwater concentrations in the central part of this unit, which was not as affected by DNAPL (Fig. 4, port 3). Redox conditions continued to be oxidizing in this part of the hydrostratigraphic unit (the average DO concentration was $8.45 \mathrm{mg} / \mathrm{L}$ between 5.00- and 5.50-m depth), which accounts for the absence of PCE reductive dechlorination as corroborated by the low concentrations of 
metabolites in the porewater (the TCE, cDCE, and VC concentrations were below the LOQ, Fig. 3 a) and groundwater (Fig. 4 f, g; port 4). In addition to these low concentrations, the isotopic composition of PCE in groundwater at port 4 in F1UB $(-25.04 \pm 0.18 \%$ ) was the lightest in the whole profile, which is evidence that PCE degradation does not occur in this unit according to Aelion et al. (2009).

Fig. 3

Porewater profiles of $\mathbf{a}$ PCE and $\mathbf{b}$ TCE in B-F1UB and B-F2UB. BLOQ: samples below the limit of quantification and $\mathbf{c}$ richness of microbial communities (i.e., the number of restriction fragments in each sample, RF) in B-F1UB and B-F2UB. Vertical scales in meters below ground surface. Dashed red lines indicate the concentration of PCE above which residual PCE-DNAPL has been observed. Green arrows show the depth at which a residual DNAPL pool of PCE was detected by the Sudan IV screening test. Blue arrows delimit the extent in depth of biodegradation haloes (see "Reductive dechorination in the transition zone" section). SZ saturated zone, USZ unsaturated zone, UDTA upper aquitard (upper discontinuous thin aquitard), UPA upper part of the aquifer, TZBA transition zone (transition zone to the basal aquitard, i.e., the lower part of the aquifer), $B A$ basal aquitard. Geological descriptions of boreholes are found in Fig. 2

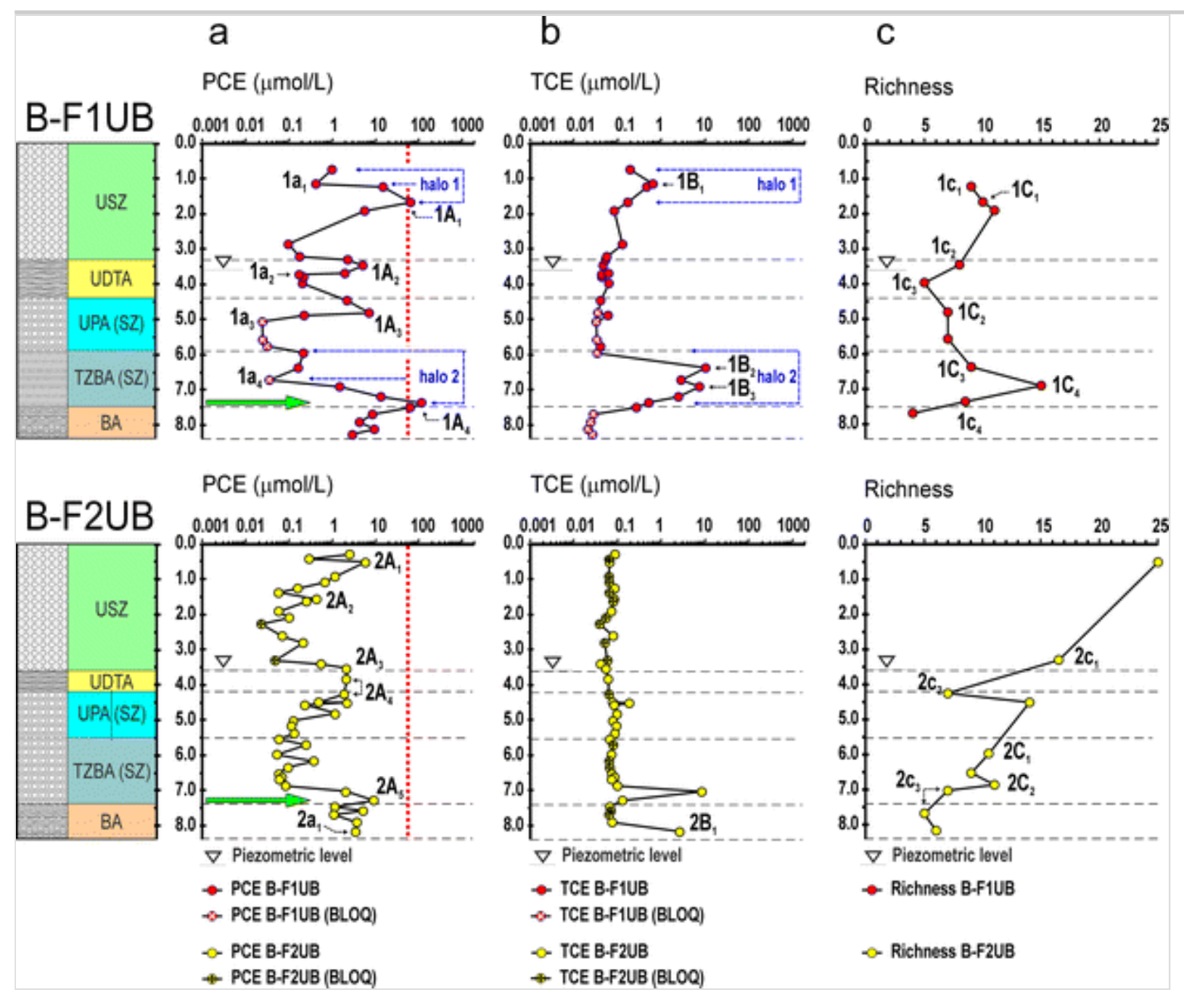


Fig. 4

Variation with depth of nitrate (a), nitrite (b), sulfate (c), Fe and Mn (d), PCE (e), TCE (f), and cDCE (g) in groundwater at the multilevel piezometers F1UB and F2UB (March 2011 and 2012). The geological descriptions of the boreholes are found in Fig. 2. Vertical scales are expressed in meters below ground surface. $S Z$ saturated zone, USZ unsaturated zone, UDTA upper aquitard (upper discontinuous thin aquitard), $U P A$ upper part of the aquifer, TZBA transition zone (transition zone to the basal aquitard, i.e., the lower part of the aquifer), $B A$ basal aquitard
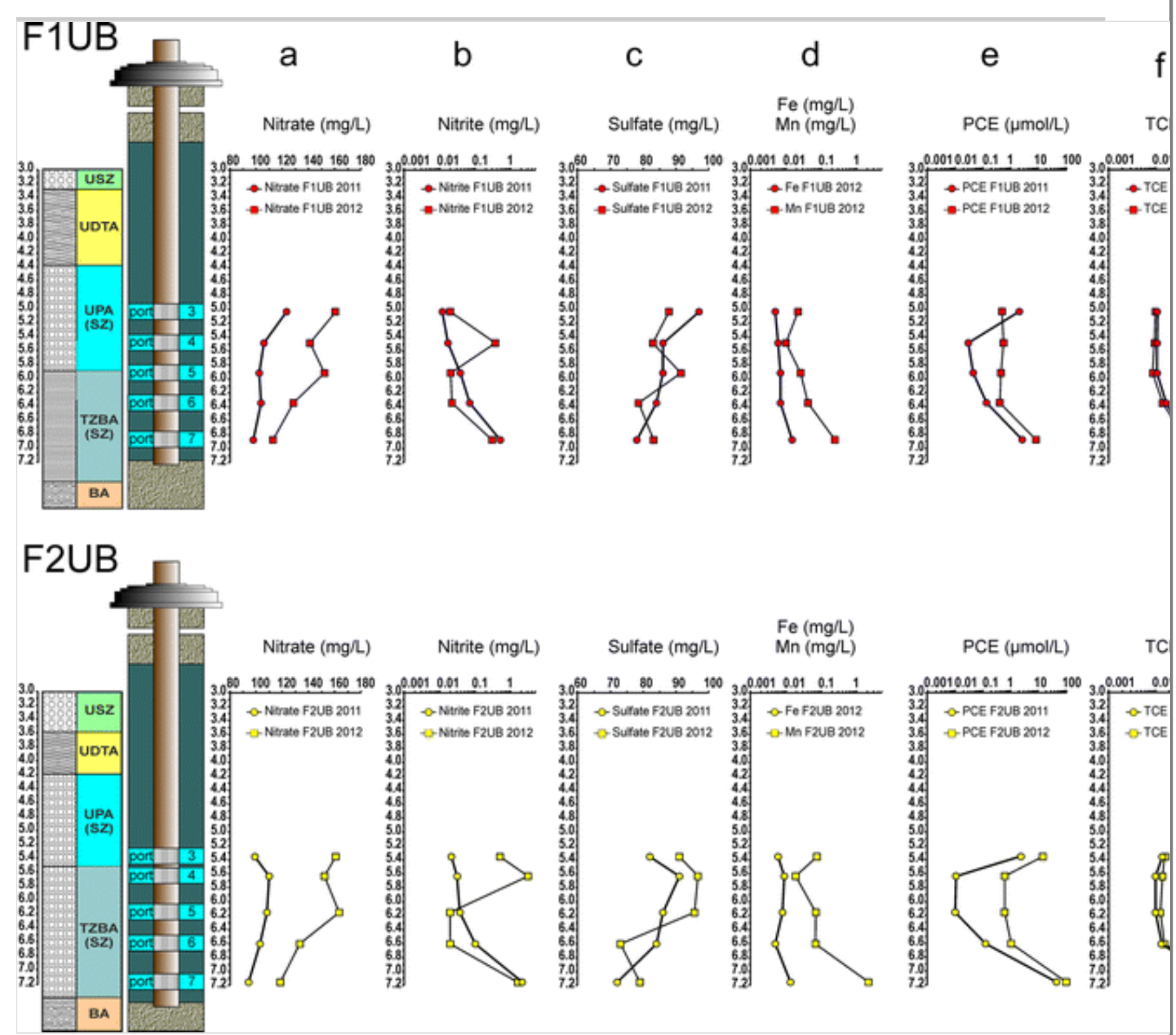

Since PCE degradation was very little in this unit at these depths, it is reasonable to suppose that, although residual DNAPL was not currently observed, the registered molar concentrations of PCE and TCE in porewater represent an estimation of the initial molar composition of the DNAPL that penetrated (assuming that DNAPL was formed by the mixture of these two compounds). However, this is only an approximation because it is impossible to know the exact effect of the changing solubility of these two compounds in the resulting 
mixture. Thus, using the average molar concentrations between depths of 3.45 and $4.80 \mathrm{~m}$ of PCE and TCE (other chloroethenes were not detected at these depths), i.e., 5.95 and $0.052 \mu \mathrm{mol} / \mathrm{L}$, respectively, molar fractions of 99.12 and $0.88 \%$, respectively, were obtained. The low molar fraction of TCE is evidence that this compound occurred as an impurity in the initial DNAPL (hence, neglecting the effect of the changing solubility most likely did not significantly influence the result of the calculation).

\section{Reductive dechorination in the transition zone}

Reducing conditions prevailed throughout the year in the groundwater in this unit (DO varied between 1.25 and $0.89 \mathrm{mg} / \mathrm{L}$ ), giving rise to denitrification with increasing depth as evidenced by the decrease in nitrate and the formation of nitrite from port 5 to 7 in F1UB and from 4 to 7 in F2UB (Fig. 4 a, b).

Furthermore, reduction processes of Mn were identified in sediments at a depth of $5.69 \mathrm{~m}$ in B-F2UB (Fig. $5 \mathrm{~b}$, label $2 \mathrm{~b}_{1}$ ) accompanied by an increase in $\mathrm{Mn}$ in the groundwater from these ports (Fig. $4 \mathrm{~d}$ ). In addition, the Sudan IV test conducted during the drilling of the two boreholes evidenced the current presence of residual DNAPL on the geological contact with the basal aquitard (see green arrows on Fig. 3 a), which accounts for the two large peaks of PCE detected near this geological contact in B-F1UB $(112.86 \mu \mathrm{mol} / \mathrm{L}$ at a $7.35-\mathrm{m}$ depth, Fig. 3 a, label $\left.1 \mathrm{~A}_{4}\right)$ and B-F2UB $(8.87 \mu \mathrm{mol} / \mathrm{L}$ at a $7.27-\mathrm{m} \mathrm{depth}$, Fig. $3 \mathrm{a}$, label $2 \mathrm{~A}_{5}$ ) in porewater and the high groundwater concentrations of PCE observed at port 7 of the two multilevel wells $(8.26$ and $104.0 \mu \mathrm{mol} / \mathrm{L}$ at locations F1UB and F2UB, respectively, in the survey of 2012; Fig. 4 e).

\section{Fig. 5}

Profiles of $\mathrm{Fe}(\mathbf{a}), \mathrm{Mn}(\mathbf{b})$, and fraction of organic carbon (c) in subsurface sediments in B-F1UB and B-F2UB. The geological descriptions of the boreholes are found in Fig. 2. Vertical scales are expressed in meters below ground surface. $S Z$ saturated zone, USZ unsaturated zone, UDTA upper aquitard (upper discontinuous thin aquitard), UPA upper part of the aquifer, TZBA transition zone (transition zone to the basal aquitard, i.e., the lower part of the aquifer), $B A$ basal aquitard 


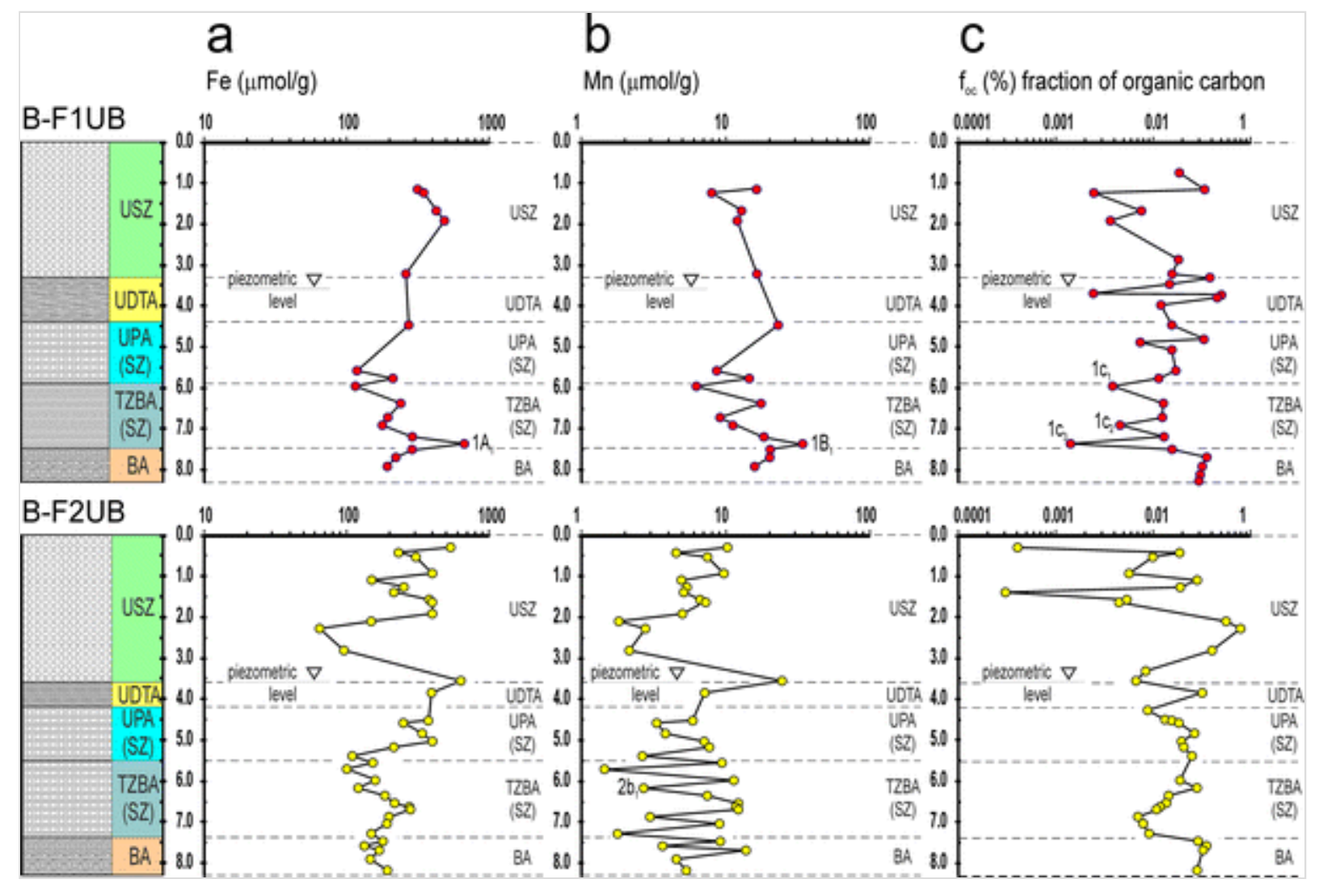

The reduction of sulfate was observed in ports 6 and 7 (Fig. 4c), which suggests that the conditions (especially in port 7) were sulfate reducing. These conditions were created as a result of a lower input of DO into the source and the consumption of this oxygen in the oxidation of the solid particulate and dissolved organic matter in the source. Hydraulic conductivity decreased because a part of the porosity was occupied by the residual DNAPL (Fetter 1993). This decrease resulted in a smaller flow velocity in the source and therefore in the aforementioned lower input of DO. In this zone near the contact with the basal aquitard, the presence of a steep concentration gradient of $\mathrm{Fe}$ (with a maximum of $667.0 \mu \mathrm{mol} / \mathrm{g}$; Fig. $5 \mathrm{a}$, label $\left.1 \mathrm{~A}_{1}\right)$ and another of Mn $(33.9 \mu \mathrm{mol} / \mathrm{g}$; Fig. $5 \mathrm{~b}$, label $1 \mathrm{~B}_{1}$ ) in the sediments of B-F1UB at a $7.35-\mathrm{m}$ depth is consistent with the aforementioned sulfate-reducing conditions. Thus, water-sediment equilibrium is achieved at this depth in which a fraction of the dissolved Fe and Mn precipitates as sulfide and/or carbonate minerals under reducing conditions (Garrels and Christ 1965; Brookings 1988).

The numerous textural changes (Table 2(A)), the fact that the number of thin layers of fine materials exceeded that of coarse-grained materials in the transition zone (Table 2(B)), and the scarcity of sand and gravel layers with no matrix (Table 2(C)) demonstrate that the medium in this zone is heterogeneous. Despite this heterogeneity, the detailed description of the transition zone of the boreholes B-F1UB and B-F2UB in Fig. 2 is perfectly embodied in the definition of transition zone (see "Introduction" section). This heterogeneity led to the accumulation of a pool of PCE on the geological contact transition zone-basal 
aquitard in the past (7.50-m depth in F1UB and 7.40-m depth in F2UB). Concentrations of the two large peaks of PCE detected near the geological contact with the basal aquitard in B-F1UB and B-F2UB, which, in milligram per liter, are 14.8 and $1.2 \mathrm{mg} / \mathrm{L}$, respectively, were lower than the current PCE effective solubility value in the residual DNAPL $\left(208.2 \mathrm{mg} / \mathrm{L}\right.$ at $\left.25^{\circ} \mathrm{C}\right)$. Given that DNAPL was detected, these lower concentrations than the effective solubility are consistent with the presence of residual PCE-DNAPL (Feenstra et al. 1991) at DNAPL saturation lower than the residual saturation (Parker et al. 2004 ) (see dashed red line in Fig. 3 a). Therefore, the aforementioned pool is currently an aged pool (i.e., composed of remnants of PCE free phase found in an immobile residual DNAPL form; Hartog et al. 2010). The values of the effective solubility of PCE and TCE $\left(208.2\right.$ and $11.2 \mathrm{mg} / \mathrm{L}$ at $25^{\circ} \mathrm{C}$, respectively) have been estimated by applying Raoult's law using the solubilities of pure phase PCE and TCE $\left(210\right.$ and $1280 \mathrm{mg} / \mathrm{L}$ at $25^{\circ} \mathrm{C}$, respectively; Lide 2003 ) and the current molar fractions calculated in the aged pool at a depth of $7.49 \mathrm{~m}$ in B-F1UB (99.57 and $0.43 \%$ for PCE and TCE, respectively; other chloroethenes were not detected at this depth). Such different values in their molar fractions (which correspond to molar concentrations of 61.5 and $0.26 \mu \mathrm{mol} / \mathrm{L}$ or 10,200 and $34.7 \mu \mathrm{g} / \mathrm{L}$, respectively, for PCE and TCE) account for the fact that the effective solubility of PCE is virtually identical to that of this compound in pure phase and is thus so different in the case of TCE.

Furthermore, the predominance of lower hydraulic conductivity layers in the transition zone resulted in a low groundwater velocity that hindered the dissolution of the PCE pool. The subsequent lower rate of dissolution contributed to the recalcitrant character of PCE in this unit (Parker et al. 2003; Chapman and Parker 2005; Adamson et al. 2014), which contrasts with the upper part of the aquifer (where only few interbedded low-conductivity layers exist, and hence, groundwater velocity was greater; Fig. 2 and Table 2(B)). Moreover, the storage of PCE by molecular diffusion (Cherry et al. 2006) in the fine-grained sediments of the transition zone contributed to the persistence of PCE in this unit, as evidenced by the progressive PCE increase in the porewater of the two boreholes (Fig. $3 \mathrm{a}, 1 \mathrm{~A}_{4}$ and $2 \mathrm{~A}_{5}$ ).

$\mathrm{AQ} 4$

As for the depth evolution of chloroethene concentrations, the existence of two depths with steep concentration gradients in TCE in the porewater of finegrained layers at depths of 6.36 and $6.90 \mathrm{~m}$ in B-F1UB, with maxima values of 10.08 and $7.29 \mu \mathrm{mol} / \mathrm{L}$, respectively (Fig. $3 \mathrm{~b}$, labels $1 \mathrm{~B} 2,1 \mathrm{~B} 3$ ), related to a maximum in $\mathrm{cDCE}(1.05 \mu \mathrm{mol} / \mathrm{L})$ and $\mathrm{VC}(0.26 \mu \mathrm{mol} / \mathrm{L})$ was noteworthy (neither of the latter two compounds is shown in Fig. 3). These four maxima of concentration were centered on a PCE minimum at a depth of $6.71 \mathrm{~m}$ 
( $0.03 \mu \mathrm{mol} / \mathrm{L}$; Fig. $3 \mathrm{a}$, label $\left.1 \mathrm{a}_{4}\right)$ and constituted a biodegradation halo (halo 2$)$, which is similar to another halo in the unsaturated zone (halo 1; Fig. $3 \mathrm{a}, \mathrm{b}$ ), indicating the biotic reductive dechlorination of PCE and metabolites, as described by Bradley (2003) and Puigserver et al. (2013). According to the observations of the latter authors, a biodegradation halo of parent and metabolite compounds is a depth interval in the profile of concentrations where a gradual increase in a metabolite (e.g., TCE) reaches a maximum and then progressively decreases, which results in a steep concentration gradient of this compound. An opposite variation of the parental compound (e.g., PCE) is produced parallel to the evolution of this metabolite. This also forms a steep concentration gradient.

In addition, the PCE groundwater at port 7 of the multilevel well F1UB (located at a depth of $6.91 \mathrm{~m}$, i.e., at the zone of halo 2) showed isotopic fractionation, with a $\delta^{13} \mathrm{C}$ value of $-23.53 \pm 0.07 \%$. This value corresponded to a $\Delta \delta$ of $+1.5 \%$ with respect to the upper part of the aquifer (where no degradation of PCE was detected; see "Reductive dechorination in the upper part of the aquifer" section). This isotopic shift is compatible with the Rayleigh fractionation curves of PCE by reductive dechlorination with enrichment factors $\varepsilon$ ranging from -0.4 to $-16.4 \%$ (Hunkeler and Morasch 2010 ), which is more evidence of PCE biodegradation forming TCE. Moreover, the $\delta^{13} \mathrm{C}$ value of the TCE in groundwater from port 7 of F1UB $(-22.10 \pm 0.30 \%$ ) was heavier than that of the parent PCE, suggesting that a fraction of the TCE was also biodegraded by reductive dechlorination (under sulfate-reducing conditions) to form $\mathrm{CDCE}$; therefore, the isotopic fractionation of TCE also occurred, according to Hunkeler et al. (2008). As for F2UB, isotopic fractionation of groundwater PCE was apparently not observed given a $\delta^{13} \mathrm{C}$ value in port 7 of $-25.02 \pm 0.16$ (at a 7.20-m depth), which is a similar value to that obtained in the upper part of the aquifer (where reductive dechlorination did not occur, and where a $\delta^{13} \mathrm{C}$ value of $-25.04 \pm 0.18 \%$ was recorded, see "Reductive dechorination in the upper part of the aquifer" section). However, the fact that the reductive dechlorination of PCE to cDCE occurred in some depth intervals provides evidence that lack of isotopic fractionation of PCE must likely due to the continuous dissolution of DNAPL at this depth masking any fractionation effect (Braeckevelt et al. 2012). The process of reductive dechlorination is also consistent with the occurrence of oxidation of solid organic matter, which is evidenced by the minimum $f_{\text {oc }}$ value recorded at this depth in B-F1UB $(0.0014 \%$ at $7.35 \mathrm{~m}$; Fig. $5 \mathrm{c}$ label $\left.1 \mathrm{c}_{4}\right)$ and in B-F2UB $(0.0069 \%$ at $7.03 \mathrm{~m}$; Fig. $5 \mathrm{c})$ (USEPA 1998; Azadpour-Keeley et al. 2001).

Although the aged pool has led to an increase in the PCE concentration in the groundwater in port 7 of the two multilevel wells and despite that the biogeochemical processes that take place compete with one another (i.e., 
reductive dechlorination, denitrification, reduction of $\mathrm{Fe}$ and $\mathrm{Mn}$, and sulfate reduction), it is noteworthy that these circumstances do not completely inhibit the reductive dechlorination of PCE to CDCE because steep increases from port 6 to port 7 in TCE and cDCE were recorded at both boreholes (Fig. $4 \mathrm{f}, \mathrm{g}$ ). The predominance of metabolites such as TCE and CDCE in the groundwater and porewater suggests that the reductive dechlorination sequence was not completed, according to Bradley (2011) and Maymó-Gatell et al. (2001), although low VC concentrations in port 7 of F1UB were also detected, with concentrations of approximately $0.080 \mu \mathrm{mol} / \mathrm{L}$ (not shown in Fig. 4).

Furthermore, the occurrence of dissolved iron in groundwater of port 7 in both multilevel wells (Fig. 4d) and also in the sediments of B-F1UB in the transition zone (Fig. 5 a, label 1 A1) suggests the presence of iron minerals (Fig. 4 c, d), as mentioned above. For this reason, it cannot be ruled out that part of the dechlorination of PCE can take place abiotically in the presence of these ferrous iron minerals.

\section{Evidence of reductive dechlorination from a microcosm experiment}

The absence of reductive dechlorination on a field scale in the upper part of the aquifer contrasts with the incomplete reductive dechlorination sequence observed in the transition zone. A similar observation was made at the laboratory scale from the microcosm experiment because no significant variations were recorded in the PCE, TCE, and cDCE concentrations from the microcosm experiment after 267 days of simulating the in situ natural attenuation in the upper part of the aquifer (first experiment, Fig. 6a). Conversely, a progressive decrease in the PCE concentration, accompanied by the formation of TCE, cDCE, and 1,1-DCE, was recorded in the natural attenuation simulation experiment in the transition zone from day 106 (second experiment, Fig. 6b) as a result of reductive dechlorination, according to Bradley (2003). The reductive dechlorination in this experiment became significant when the sulfate concentration declined from $43.73 \mathrm{mg} / \mathrm{L}$ (day 106) to $16.72 \mathrm{mg} / \mathrm{L}$ (day 267), i.e., after the sulfate reduction conditions were reached. Therefore, although incomplete, reductive dechlorination is a more important biogeochemical process in the transition zone than in the upper part of the aquifer, which supports the observations at the field site. Furthermore, controls of these two experiments did not show any variation in concentrations of the PCE injected or metabolite formation (Fig. 6c,d). Therefore, abiotic degradation did not occur in the microcosm experiments, which does not imply that it does not occur at field scale, as indicated at the end of "Reductive dechorination in the transition zone" section. 
Aqueous concentrations in microcosm experiments used to simulate natural attenuation. Error bars show the range of variation in duplicates. a In the upper part of the aquifer (first experiment, active tests). Red line indicates that up to 267 days (end of experiment), concentrations did not substantially change. b In the transition zone (second experiment, active tests). Red line indicates that from day 106, there were substantial changes in concentrations. c In the upper part of the aquifer (first experiment, control tests). d In the transition zone (second experiment, control tests). TCE and CDCE concentrations of first sampling day in control tests correspond to the groundwater sample used in the experiments after purging (see "Microcosm set-up and monitoring" section)
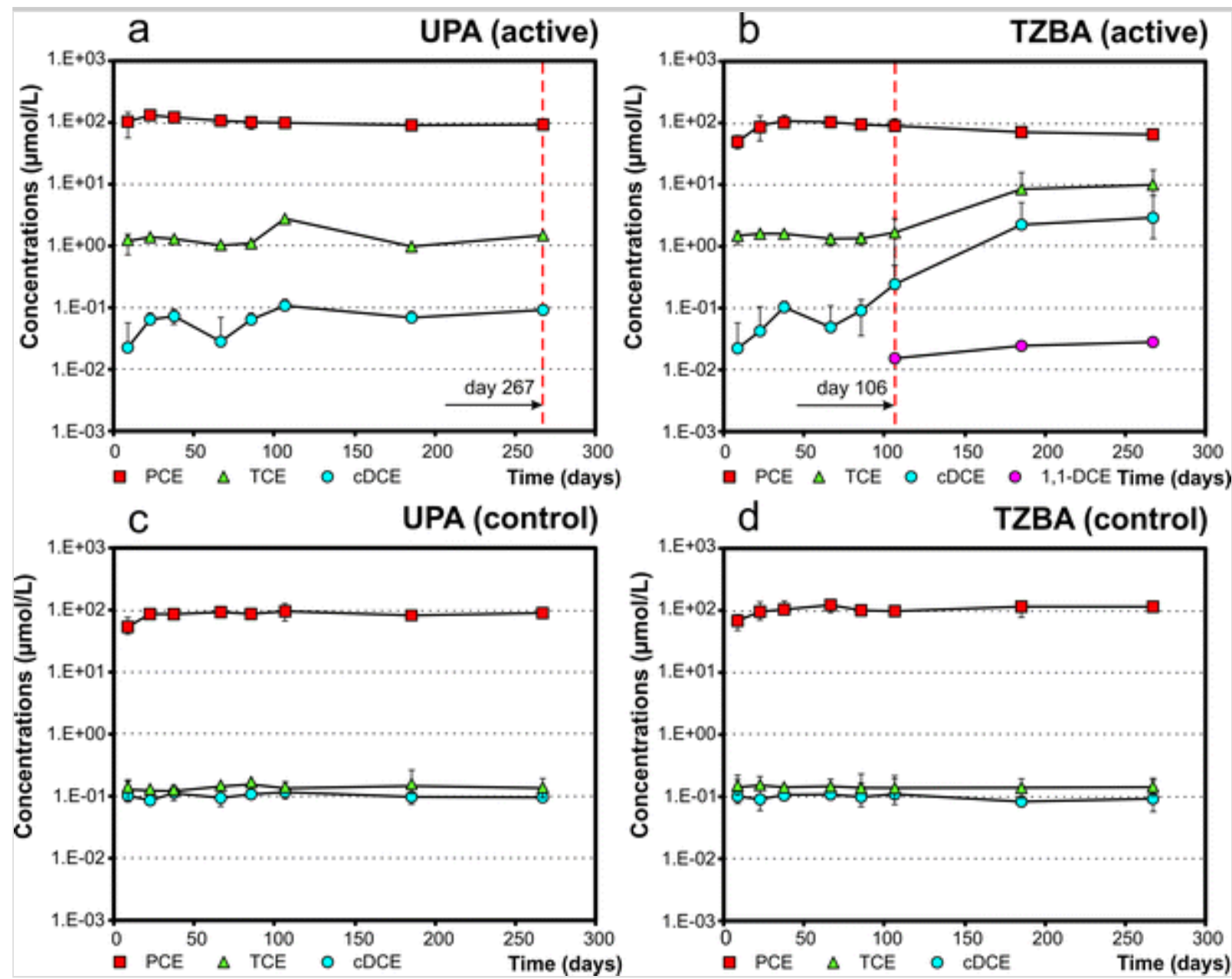

\section{Effects of high concentrations of chloroethenes on microbial communities}

The peaks of PCE in porewater immediately below the contact unsaturated zoneupper aquitard (Fig. 3 a, labels $1 \mathrm{~A}_{2}$ and $2 \mathrm{~A}_{3}$; see "Reductive dechorination in the upper part of the aquifer" section) coincided with a decrease in richness, i.e., the number of different species in the community (Fig. $3 \mathrm{c}$, labels $1 \mathrm{c} 2$ and $2 \mathrm{c} 1$ ) when compared with the upper unit. This decrease is attributable to an increase in the specialization of microbial populations because many of these cannot adapt to high concentrations of PCE (Sleep et al. 2006). Moreover, the minimum value of 
PCE in porewater at a depth of $3.96 \mathrm{~m}$ in fine and medium sands within the upper aquitard at B-F1UB $\left(0.17 \mu \mathrm{mol} / \mathrm{L}\right.$, Fig. $3 \mathrm{a}$, label $\left.1 \mathrm{a}_{2}\right)$ coincided with a minimum of richness (Fig. $3 \mathrm{c}$, label $1 \mathrm{c}_{3}$ ). This minimum is related to the absence of groundwater flow in these sands, which prevents microbial communities from gaining access to the nutrients, electron donors, carbon sources, and growth factors (natural substances that stimulate the growth, proliferation, differentiation, and cellular healing) that they need. Therefore, the most suitable conditions for the development of microbial communities were not met in these sands. The concentrations of PCE in porewater recorded in the aforementioned pronounced peaks immediately below the contact upper aquitard-upper part of the aquifer (Fig. 3 a, labels $1 \mathrm{~A}_{3}$ and $2 \mathrm{~A}_{4}$; see "Reductive dechorination in the upper part of the aquifer" section) corresponded with lower richness of microbial communities (Fig. $3 \mathrm{c}$; labels $1 \mathrm{C}_{2}$ and $2 \mathrm{c}_{2}$ for B-F1UB and $\mathrm{B}-\mathrm{F} 2 \mathrm{UB}$, respectively) than those on the contact unsaturated zone-upper aquitard (Fig. 3c).

In the biodegradation halo centered on a PCE minimum in porewater at a depth of $6.71 \mathrm{~m}\left(0.03 \mu \mathrm{mol} / \mathrm{L}\right.$; Fig. $3 \mathrm{a}$, label $1 \mathrm{a}_{4}$; halo 2 , see "Reductive dechorination in the transition zone" section), a significant increase in the microbial richness of microbial communities was recorded in B-F1UB at a depth of $6.90 \mathrm{~m}$ (Fig. 3c label $1 \mathrm{C}_{4}$, with maximum relative value of 9) compared with the top of the transition zone and the upper part of the aquifer. This increase is consistent with the coexistence of the aforementioned biogeochemical processes (denitrification, reduction of $\mathrm{Fe}$ and $\mathrm{Mn}$, sulfate reduction, and reductive dechlorination; see "Reductive dechorination in the transition zone" section). The aforementioned high peaks of PCE in porewater in the transition zone near the contact with the basal aquitard (Fig. $3 \mathrm{a}$, label $1 \mathrm{~A}_{4}$ and $2 \mathrm{~A}_{5}$; in B-F1UB and B-F2UB, respectively) diminished the richness (Fig. $3 \mathrm{c}$, labels $1 \mathrm{c}_{4}$ and $2 \mathrm{c}_{3}$; with relative average values of 8 and 6 in B-F1UB and B-F2UB, respectively) compared with the upper part of the transition zone in contact with the upper part of the aquifer (Fig. $3 \mathrm{c}$, labels $1 \mathrm{C}_{3}$ and $2 \mathrm{C}_{1}$ in B-F1UB and B-F2UB, respectively). These findings would suggest that high concentrations of PCE negatively affect this parameter of the structure of microbial communities, as reported by Haack and Bekins (2000).

\section{Dechlorinating community in the sediments of the transition zone}

The nested PCR technique allowed the identification of Dehalococcoides sp. in the transition zone, and the clone library analysis allowed the identification of other microorganisms in this zone. The clone library was established to compare the microbial communities in the aged pool and halo 2 (Fig. 7). Particular 
attention was paid to the clones related to the microorganisms that are reductively or oxidatively dechlorinating and those that are fermenting (because of their relationship with reductively dechlorinating microorganisms).

\section{Fig. 7}

Phylogenetic tree of the identified bacteria in the two sampled depths of borehole B-F1UB. This tree has been produced based on the partial sequences of the $16 \mathrm{~S}$ rRNA. The total number of sequenced clones was 47 for each of the two samples. Blue: the sample taken at $6.90-\mathrm{m}$ depth at the maximum TCE concentration located in the biodegradation halo 2. Orange: the sample taken at $7.35-\mathrm{m}$ depth in the aged pool of PCE. The values in brackets are the percentage of similitude of clones with the related microorganisms. The circle diameters correspond to the number of identified clones (from 1 to 19). Values in brackets are the percentage of similitude of clones with the related microorganisms. Diameter of circles corresponds to the number of identified clones (from 1 to 19). Microorganism naming follows the National Center for Biotechnology Information (NCBI, USA)

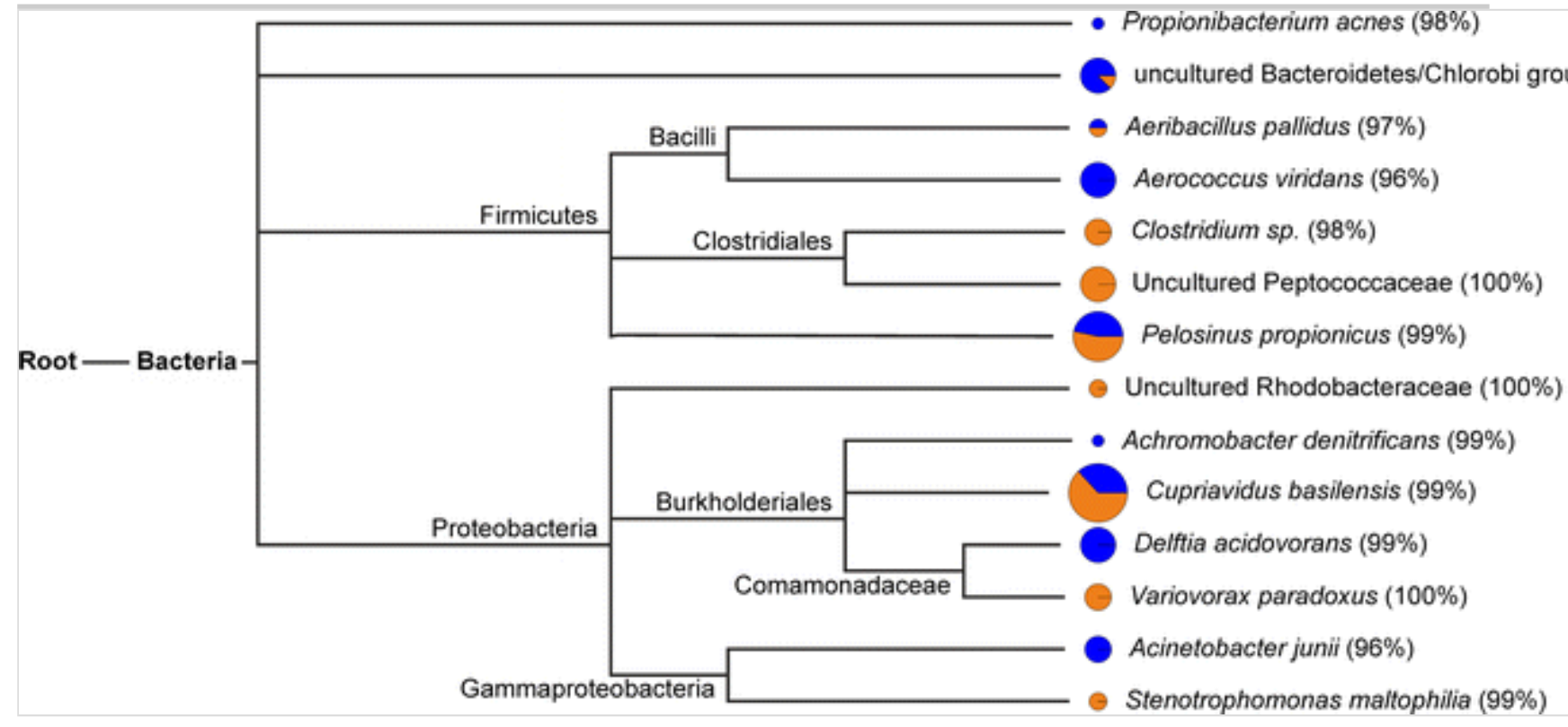

Dechlorinating and fermenting microorganisms were identified at $6.90-\mathrm{m}$ depth, coinciding with the maximum of TCE concentration in porewater located in the biodegradation halo 2 (Fig. $3 \mathrm{~b}$ label $1 \mathrm{~B}_{3}$ ), i.e., immediately above the aged pool of PCE. Among the fermenting microorganisms, uncultured Bacteroidetes, Propionibacterium acnes, and Pelosinus propionicus were identified. These microorganisms generate propionic acid and $\mathrm{H}_{2}$ (Patil et al. 2014). In addition, P. propionicus is capable of synthesizing the corrinoids that some OHRB of $\mathrm{cDCE}$ and VC need to carry out the complete reductive dechlorination of chloroethenes (Men et al. 2014). As for the OHRB, P. acnes and Dehalococcoides sp. were detected. Of these, $P$. acnes is capable of reductively dechlorinating PCE and TCE under anaerobic conditions (Chang et al. 2011), 
whereas the genus Dehalococcoides is capable of dechlorination past cDCE to VC and ethane (Maymó-Gatell et al. 2001). Among the oxidatively dechlorinating microorganisms detected were Delftia acidovorans (which is able to degrade high concentrations of TCE under aerobic conditions; Park and Lee 2013 ), Achromobacter denitrificans and Acinetobacter junii (which cometabolically degrade isomers of DCE, Olaniran et al. 2008), and Cupriavidus basilensis (which is able to cometabolically degrade TCE in the presence of phenol, Estrada-de Los Santos et al. 2011).

The greater richness of microbial communities, especially in B-F1UB, coincides with the presence of fermenting (P. propionicus and Bacteroides), reductively dechlorinating (Dehalococcoides sp. and P. acnes), and oxidatively dechlorinating (D. acidovorans, A. denitrificans, A. junii, and C. basilensis) microorganisms. The presence of these microorganisms under conditions ranging from microaerophilic to the reduction of Mn, along with the coexistence of numerous biogeochemical processes (see "Reductive dechorination in the transition zone" section), is evidence of partially inhibited reductive dechlorination by microbial competition. However, the presence of OHRB and PCE metabolites and the fact that dissolved PCE presents isotopic fractionation (see "Reductive dechorination in the transition zone" section) show the existence of reductive dechlorination, which corroborates the working hypothesis. Furthermore, the presence of TCE and CDCE oxidatively dechlorinating microorganisms suggests that a fraction of these two compounds may have been degraded by a metabolic pathway different from that of reductive dechlorination.

As for the zone where the aged pool is located (at a depth of $7.40 \mathrm{~m}$, on the geological contact transition zone-basal aquitard), the greater clone frequencies corresponded to those of microorganisms with the fermentative metabolism of the phyla Bacteroidetes (uncultured Bacteroidetes) and Firmicutes ( $P$. propionicus, Clostridium sp., and uncultured Peptococcaceae) (Patil et al. 2014). Among the OHRB, the following were identified: Dehalococcoides sp. (Maymó-Gatell et al. 1997), Clostridium bifermentans (a microorganism that has been characterized as able to degrade PCE to CDCE via TCE; Okeke et al. 2001), and Clostridium sp. strain DC1 (capable of cometabolically degrading isomers of DCE and VC; Kim et al. 2006). The oxidatively dechlorinating microorganisms identified are C. basilensis and Variovorax paradoxus (which are capable of cometabolically degrading TCE in the presence of phenol; Futamata et al. 2005; Humphries et al. 2005) and Stenotrophomonas maltophilia (able to grow using only TCE as a carbon source; Mukherjee and Roy 2012).

In this geological contact, the high concentrations of PCE caused by the presence 
of an aged PCE pool partially inhibit the microbial communities, as suggested by the decline in the richness of microbial communities (Fig. $3 \mathrm{c}$ label 1 $\mathrm{c}_{4}$ ).

However, a higher proportion of fermenting microorganisms (Bacteroides, Clostridium sp., Peptococcaceae, and P. propionicus) compared with the zone of halo 2 ensures an important supply of $\mathrm{H}_{2}$ as a source of electrons for the OHRB (Dehalococcoides and Clostridium), which have been identified in environment in the presence of DNAPL (Chang et al. 2000; Schaefer et al. 2010). In addition, the prevalence of sulfate-reducing conditions favors the reductive dechlorination of PCE and TCE, as evidenced by the presence of $\mathrm{CDCE}$ and traces of $\mathrm{VC}$ in the B-F1UB porewater, also corroborating the working hypothesis at this depth. Nevertheless, the identification of oxidatively dechlorinating microorganisms also at this depth suggests that conditions may be locally microaerophylic and that it cannot be ruled out that a fraction of TCE and cDCE may have been degraded by a metabolic pathway different from that of reductive dechlorination.

The determined sequence data of 16S rRNA genes of the bacteria in Fig. 7 have been deposited in the European Nucleotide Archive (ENA). The accession numbers are listed in Table 3 .

Table 3

ENA accession numbers of the bacteria in Fig. 7

\begin{tabular}{|l|l|}
\hline \multicolumn{1}{|c|}{ Description } & \multicolumn{1}{|c|}{ Accession number } \\
\hline Propionibacterium acnes & LN998003 \\
\hline Uncultured Bacteroidetes/Chlorobi group bacterium & LN998004 \\
\hline Aeribacillus pallidus & LN998005 \\
\hline Aerococcus viridans & LN998006 \\
\hline Clostridium sp. B010 & LN998007 \\
\hline Uncultured Peptococcaceae bacterium & LN998008 \\
\hline Pelosinus propionicus & LN998009 \\
\hline Uncultured Rhodobacteraceae bacterium & LN998010 \\
\hline Achromobacter denitrificans & LN998011 \\
\hline Cupriavidus basilensis & LN998012 \\
\hline Delftia acidovorans & LN998013 \\
\hline Variovorax paradoxus & LN998014 \\
\hline Acinetobacter junii & LN998015 \\
\hline Stenotrophomonas maltophilia & LN998016 \\
\hline
\end{tabular}




\section{Evidence that reductive dechlorination of PCE and TCE is favored in the transition zone in contrast to the upper part of the aquifer and implications for remediation}

Several pieces of evidence support the observation that biotic reductive dechlorination of PCE and TCE is favored in the transition zone: (1) the numerous geological heterogeneities and textural changes in the transition zone (see "Hydrostratigraphic units differentiated in the subsurface" section) enable the different microorganisms to gain access to nutrients, electron acceptors, electron donors, carbon sources, and growth factors reaching this unit along the layers of larger grain size, and hence pore size, materials. Microorganisms also have access to the solid organic matter and chloroethenes along the surface of contact with fine materials similar to that described by Puigserver et al. (2014) in an alluvial aquifer. (2) The transition zone is located at the interface between the oxic medium of the upper part of the aquifer (see "Reductive dechorination in the upper part of the aquifer" section) and the anoxic medium generated by the presence of the aged PCE pool at the transition zone-basal aquitard geological contact (see "Reductive dechorination in the transition zone" section), which resulted in a high microbial richness in this unit (Fig. $3 \mathrm{c}$, labels $1 \mathrm{C}_{4}$ and $2 \mathrm{C}_{2}$ ). 3) Numerous biogeochemical processes, such as denitrification, the reduction of $\mathrm{Fe}$ and $\mathrm{Mn}$, sulfate reduction, and the reductive dechlorination of PCE and TCE (see "Reductive dechorination in the transition zone" section), related to a large richness of microbial communities (Fig. $3 \mathrm{c}$, labels $1 \mathrm{C}_{4}$ and $2 \mathrm{C}_{2}$ ) that includes the presence of OHRB (see "Dechlorinating community in the sediments of the transition zone" section), coexist in this zone (see "Effects of high concentrations of chloroethenes on microbial communities" section).

In contrast to the upper part of the aquifer (where the biodegradation of PCE and TCE was not observed), the transition zone groundwater showed presence of the metabolites of PCE and TCE and the isotopic fractionation of PCE (see "Reductive dechorination in the transition zone" section) and, hence, reveal the presence of reductive dechlorination.

Despite the presence of microorganisms capable of completing reductive dechlorination (Dehalococcoides and Clostridium), this process is not significant, and major amounts of TCE and $\mathrm{CDCE}$ accumulate in the transition zone. Redox conditions were not a limiting factor for complete reductive dechlorination because this process also did not occur in the transition zone 
microcosm experiment, where sulfate-reducing conditions were achieved (see "Evidence of reductive dechlorination from a microcosm experiment" section). These findings, and the fact that no significant variations in the PCE, TCE, and cDCE concentrations were recorded in the upper part of the aquifer natural attenuation microcosm experiment, suggest that one of the major limiting factors for completing reductive dechlorination may be a small supply of bioavailable electron donors. According to Rifai et al. (2011), this suggests that an adequate supply of fermentable substrates is needed for the production of dissolved hydrogen, which is used directly by OHRB as the electron donor. For this reason, biostimulation (and/or bioaugmentation) in the transition zone by adding electron donors could be more efficient than in the upper part of the aquifer, where the richness of microbial communities tends to be lower. Moreover, although microcosms were not replenished with electron donors and substrates, as would occur in the field, and despite the fact that this microcosm study is a snapshot in time, it reinforces the possible use of biostimulation and/or bioaugmentation to improve degradation rates in order to accelerate degradation and to enhance the subsequent dissolution of more DNAPL, which provides greater value and significance to our findings.

Moreover, we previously studied a contaminated transition zone by chlorinated solvents at another site (Puigserver et al. 2013, see "Introduction" section). This transition zone was also characterized by a large diversity of microorganisms, which included OHRB (Puigserver et al. 2016), and also was located in deposits of distal prograding alluvial fans in the geological context of the Catalan Coastal Ranges (i.e., different to the context of the present study). Given that similar observations to those obtained in the current study were made, it is reasonable to think that in cases of transition zones contaminated by chlorinated solvents and geologically located in alluvial fan deposits similar to that of the current study, the characteristics of this contamination and its temporal evolution could be similar to that of the present work.

AQ5

AQ6

\section{Conclusions}

Our study shows the enormous variability in geochemical and microbiological results. In order to understand what this involves and in order to interpret this variability, it is essential to carry out a detailed geochemical and microbiological sampling. This variability is associated with (i) the heterogeneity of sediments (variations in hydraulic conductivity), (ii) the redox conditions, and (iii) the chloroethene concentration; i.e., it increases on high-low hydraulic conductivity boundaries, where DNAPL-mass persistence occurs. 
Furthermore, natural attenuation by biodegradation in porewater is noteworthy since it helps to maintain steep chloroethene concentration gradients (strong concentration variability) that create a large mass diffusion flux. This mass biodegrades at a rate that maintains these gradient steeps. The natural dechlorinating activity by OHRB and the more efficient natural transformation of PCE into TCE in the transition zone than in the rest of the aquifer are of considerable environmental significance. Therefore, bioremediation via reductive dehalogenation in the transition zone may be applied more efficiently to promote complete reductive dechlorination and to enhance the subsequent dissolution of more DNAPL in these zones than in other parts of the aquifer. Hence, removal of the source would be accelerated and the effects of back diffusion could be reduced or eliminated. Thus, biostimulation of the dechlorinating indigenous microbial communities and/or bioaugmentation may be conducted by making the site more anoxic and providing an electron donor.

Furthermore, the environmental importance of our work lies in the fact that many supply wells in the world exploit aquifers, which are constituted by materials that correspond to recent unconsolidated alluvial fan deposits and that form the principal groundwater source. Extraction wells are easy to drill and their groundwater is easily accessible. Alluvial fans fill basins where land use devoted to drinking water and to industry could lead to the contamination of aquifers with chlorinated solvents.

\section{Acknowledgments}

We are indebted to the Catalan Water Agency and to the members of INTERFREN of Figueres and INTECSON S.L. of Reus for their support and cooperation while conducting the fieldwork. We would also like to thank our colleagues of the Department of Geochemistry, Petrology, and Geological Prospecting of the University of Barcelona and especially the members of the hydrogeology group of that department. We are grateful to the ScientificTechnical Services personnel of the University of Barcelona for their help in analyzing the samples. We would also like to acknowledge the institution funding the research conducted within the following projects: CTM 2005-07824 and CGL 2008-02164/BTE (Spanish Ministry of Education).

\section{Electronic supplementary material}

\section{ESM 1}

(DOCX $27 \mathrm{~kb})$ 


\section{References}

Adamson DT, Chapman S, Mahler N, Newell C, Parker BL, Pitkin S, Rossi M, Singletary M (2014) Membrane Interface probe protocol for contaminants in low-permeability zones. Ground Water 52(4):550-565

Aelion CM, Höhener P, Hunkeler D, Aravena R (Eds) (2009) Environmental isotopes in biodegradation and bioremediation. CRC Press

Aulenta F, Pera A, Rossetti S, Papini MP, Majone M (2007) Relevance of side reactions in anaerobic reductive dechlorination microcosms amended with different electron donors. Water Res 41(1):27-38

Azadpour-Keeley A, Keeley JW, Russell HH, Sewell GW (2001) Monitored natural attenuation of contaminants in the subsurface: processes. Groundwater Monit Rem 21(2):97-107

Bouwer EJ (1994) Bioremediation of chlorinated solvents using alternate electron acceptors. In: Norris RD et al (eds) Handbook of bioremediation. Lewis Publishers, p. 149-175

Bradley PM (2003) History and ecology of chloroethene biodegradation: a review. Biorem J 7:81-109

Bradley PM (2011) Reinterpreting the importance of oxygen based biodegradation in chloroethene contaminated groundwater. Ground Water Monit Rem 31(4):50-55

Bradley PM, Chapelle FH (2011) Microbial mineralization of dichloroethene and vinyl chloride under hypoxic conditions. Ground Water Monit Rem 31(4):39-49

Braeckevelt M, Fischer A, Kästner M (2012) Field applicability of compound-specific isotope analysis (CSIA) for characterization and quantification of in situ contaminant degradation in aquifers. Appl Microbiol Biotechnol: 1-21

Brookings DG (1988) Eh-Ph diagrams for geochemistry. Springer Verlag, New York

Chang YC, Hatsu M, Jung K, Yoo YS, Takamizawa K (2000) Isolation and 
characterization of a tetrachloroethylene dechlorinating bacterium, Clostridium bifermentans DPH-1. J Biosci Bioeng 89(5):489-491

Chang YC, Ikeutsu K, Toyama T, Choi D, Kikuchi S (2011) Isolation and characterization of tetrachloroethylene-and cis-1, 2-dichloroethylenedechlorinating propionibacteria. J Ind Microbiol Biotechnol 38(10):16671677

Chapelle FH (1996) Quantifying rates of biodegradation in contaminated aquifers. In: Kobus $\mathrm{H}$ et al. (eds) Groundwater and subsurface remediation. Springer, Berlin Heidelberg, pp. 67-75

Chapman SW, Parker BL (2005) Plume persistence due to aquitard back diffusion following dense nonaqueous phase liquid source removal or isolation. Water Resour Res 41(12):W12411

Chapman SW, Parker BL, Cherry JA, Aravena R, Hunkeler D (2007) Groundwater-surface water interaction and its role on TCE groundwater plume attenuation. J Contam Hydrol 91(3):203-232

Chapman SW, Parker BL, Sale TC, Doner LA (2012) Testing high resolution numerical models for analysis of contaminant storage and release from low permeability zones. J Contam Hydrol 136:106-116

Cherry JA, Parker BL, Bradbury KR, Eaton TT, Gotkowitz MB, Hart DJ, Borchardt MA (2006) Contaminant transport through aquitards: a state-ofthe-science review. American Water Works Association, AWWA (Ed.). Research Foundation, and International Water Well Association, IWA. Denver, Colorado, U.S.A.

Duhamel M, Edwards EA (2006) Microbial composition of chlorinated ethene-degrading cultures dominated by Dehalococcoides. FEMS Microbiol Ecol 58:538-549. doi: 10.1111/j.1574-6941.2006.00191.x

Duhamel M, Mo K, Edwards EA (2004) Characterization of a highly enriched Dehalococcoides-containing culture that grows on vinyl chloride and trichloroethene. Appl Environ Microbiol 70:5538-5545. doi:

10.1128/AEM.70.9.5538-5545.2004

Einarson MD, Cherry JA (2002) A new multilevel ground water monitoring system using multichannel tubing. Groundwater Monit Rem 22(4):52-65 
Estrada-de Los Santos P, Vacaseydel-Aceves NB, Martínez-Aguilar L, CruzHernández MA, Mendoza-Herrera A, Caballero-Mellado J (2011)

Cupriavidus and Burkholderia species associated with agricultural plants that grow in alkaline soils. J Microbiol 49(6):867-876

Feenstra S, Mackay DC, Cherry JA (1991) A method assessing residual NAPL based on organic chemical concentrations in soil samples. Ground Water Monit Rev 1991:128-136

Fetter CW (1993) Contaminant hydrogeology. MacMillan Publishing Company, New York

Futamata H, Nagano Y, Watanabe K, Hiraishi A (2005) Unique kinetic properties of phenol-degrading variovorax strains responsible for efficient trichloroethylene degradation in a chemostat enrichment culture unique kinetic properties of phenol-degrading Variovorax strains responsible for efficient trichloro. Appl Environ Microbiol 71(2):904-911

Garrels RM, Christ CL (1965) Solutions, minerals and equilibria. Harper and Row, New York and John Weatherhill, Inc, Tokyo

Haack SK, Bekins BA (2000) Microbial populations in contaminant plumes. Hydrogeol J 8(1):63-76

Hartog H, Cho J, Parker BL, Annable MD (2010) Characterization of a heterogeneous DNAPL source zone in the Borden aquifer using partitioning and interfacial tracers: residual morphologies and background sorption. $\mathrm{J}$ Contam Hydrol 115(1):79-89

\section{Holliger C, Hahn D, Harmsen H, Ludwig W, Schumacher W, Tindall B, Zehnder AJ (1998) Dehalobacter restrictus gen. nov. and sp. nov, a strictly anaerobic bacterium that reductively dechlorinates tetra-and trichloroethene in an anaerobic respiration. Areh Mierobiol 169(4):313 321}

Humphries JA, Ashe AMH, Smiley JA, Johnston CG (2005) Microbial community structure and trichloroethylene degradation in groundwater. J Microbiol 51:433-439

Hunkeler D, Morasch B (2010) Isotope fractionation during transformation processes. In: Aelion CM, Höhener P, Hunkeler D, Aravena R (eds)

Environmental isotopes in biodegradation and bioremediation. CRC Press, pp $79-125$ 
Hunkeler D, Meckenstock R, Sherwood Lollar B, Schmidt T, Wilson T (2008) A guide for assessing biodegradation and source identification of organic ground water contaminants using compound specific isotope analysis (CSIA). Office of Research and Development, National Risk Management Research Laboratory, US Environmental Protection Agency

IGC (1996) Mapa Geològic de Catalunya 1:25.000. No. 258-1-2 (77-22): Navata. Institut Cartogràfic de Catalunya. Servei Geològic de Catalunya. Barcelona

IGME (1994) Mapa Geológico de España 1:50.000. No. 258: Figueres. Instituto Geológico y Minero de España, Madrid

Johnston D (2006) Draft EPA guidelines regulatory monitoring and testing groundwater sampling, 56, Environment Protection authority (EPA) Australia

Kim ES, Nomura I, Hasegawa Y, Takamizawa K (2006) Characterization of a newly isolatedcis-1, 2-dichloroethylene and aliphatic compound-degrading bacterium, clostridium sp. strain KYT-1. Biotechnol Bioprocess Eng 11:553556

Lide DR (2003) Handbook of chemistry and physics, 84th edn. CRC Press Ltd., New York

Löffler FE, Sun Q, Li J, Tiedje JM (2000) 16S rRNA gene-based detection of tetrachloroethene-dechlorinating Desulfuromonas and Dehalococcoides species. Appl Environ Microbiol 66(4):1369-1374

Mackay D, Shiu WY, Ma KC, Lee SC (2006) Handbook of physical-chemical properties and environmental fate for organic chemicals. CRC press

Maymó-Gatell X, Chien Y, Gossett JM, Zinder SH (1997) Isolation of a bacterium that reductively dechlorinates tetrachloroethene to ethene. Science 276(5318):1568-1571

Maymó-Gatell X, Nijenhuis I, Zinder SH (2001) Reductive dechlorination of cis-1, 2-dichloroethene and vinyl chloride by "Dehalococcoides ethenogenes”. Environ Sci Technol 35(3):516-521

MeMurdie PJ, Behrens SF, Müller JA, Göke J, Ritalahti KM, Wagner R, Spormann AM (2009) Localized plasticity in the streamlined genomes of vinyl chloride respiring Dehalococcoides. PLoS Genet 5(11):e1000714 
Men Y, Seth EC, Yi S, Allen RH, Taga ME, Alvarez-Cohen L (2014) Sustainable growth of Dehalococcoides mccartyi 195 by corrinoid salvaging and remodeling in defined lactate-fermenting consortia. Appl Environ Microbiol 80:2133-2141

Mercer JW, Cohen RM (1990) A review of immiscible fluids in the subsurface: properties, models, characterization and remediation. J Contam Hydrol 6(2):107-163

Miller E, Wohlfarth G, Diekert G (1996) Studies on tetrachloroethene respiration in Dehalospirillum multivorans. Arch Microbiol 166:379-387

Mukherjee P, Roy P (2012) Identification and characterisation of a bacterial isolate capable of growth on trichloroethylene as the sole carbon source. Adv Microbiol 02(03):284-294

National Research Council (1999) Improving management of persistent of contaminants. Groundwater and soil cleanup. National Academic Press, Washington, DC, pp. 113-174

Okeke BC, Chang YC, Hatsu M, Suzuki T, Takamizawa K (2001) Purification, cloning, and sequencing of an enzyme mediating the reductive dechlorination of tetrachloroethylene (PCE) from clostridium bifermentans DPH-1. Can J Microbiol 47(5):448-456

Olaniran AO, Pillay D, Pillay B (2008) Aerobic biodegradation of dichloroethenes by indigenous bacteria isolated from contaminated sites in Africa. Chemosphere 73(1):24-29

Park W, Lee S (2013) The biological degradation of high concentration of trichloroethylene (TCE) by Delftia acidovornas EK2. Korean J Microbiol 46

Parker BL, Gillham RW, Cherry JA (1994) Diffusive disappearance of immiscible phase organic liquids in fractured geologic media. Ground Water 32(5):805-820

Parker BL, Cherry JA, Chapman SW, Guilbeault MA (2003) Review and analysis of chlorinated solvent dense nonaqueous phase liquid distributions in five Sandy aquifers. Vadose Zone J 2:116-137

Parker BL, Cherry JA, Chapman SW (2004) Field study of TCE diffusion profiles below DNAPL to assess aquitard integrity. J Contam Hydrol 
Parker BL, Chapman SW, Guilbeault MA (2008) Plume persistence caused by back diffusion from thin clay layers in a sand aquifer following TCE sourcezone hydraulic isolation. J Contam Hydrol 102(1):86-104

Patil SS, Adetutu EM, Aburto-Medina A, Menz IR, Ball AS (2014) Biostimulation of indigenous communities for the successful dechlorination of tetrachloroethene (perchloroethylene)-contaminated groundwater. Biotechnol Lett 36(1):75-83

\section{Popat SC, Deshusses MA (2011) Kinetics and inhibition of reductive dechlorination of trichloroethene, cis-1,2-dichloroethene and vinyl chloride in a continuously fed anaerobic biofilm reactor. Environ Sei Technol $45(4): 1569-1578$}

Puigserver D, Carmona JM, Cortés A, Viladevall M, Nieto JM, Grifoll M, Parker BL (2013) Subsoil heterogeneities controlling porewater contaminant mass and microbial diversity at a site with a complex pollution history. $\mathrm{J}$ Contam Hydrol 144(1):1-19

Puigserver D, Cortés A, Viladevall M, Nogueras X, Parker BL, Carmona JM (2014) Processes controlling the fate of chloroethenes emanating from DNAPL aged sources in river-aquifer contexts. J Contam Hydrol 168:25-40 Puigserver D, Nieto JM, Grifoll M, Vila J, Cortés A, Viladevall M, Parker BL, Carmona JM (2016) Temporal hydrochemical and microbial variations in microcosm experiments from sites contaminated with chloromethanes under biostimulation with lactic acid. Bioremediation Journal, 20(1):54-70

Puls RW, Barcelona MJ (1996) Low-flow (minimal drawdown) ground-water sampling procedures. US Environmental Protection Agency, Office of Research and Development, Office of Solid Waste and Emergency Response. EPA Ground Water Issue

Rifai HS, Newell CJ, Wiedemeier TH (2011) Contamination cleanup: natural attenuation and advanced remediation technologies. Handbook of solvents. William Andrew, Toronto, pp. 1572-1630

Rivett MO, Dearden RA, Wealthall GP (2014) Architecture, persistence and dissolution of a 20 to 45 year old trichloroethene DNAPL source zone. J 
Sale TC, Zimbron JA, Dandy DS (2008) Effects of reduced contaminant loading on downgradient water quality in an idealized two-layer granular porous media. J Contam Hydrol 102(1):72-85

Schaefer CE, Towne RM, Vainberg S, McCray JE, Steffan RJ (2010) Bioaugmentation for treatment of dense non-aqueous phase liquid in fractured sandstone blocks. Environ Sci Technol 44(1):4958-4964

Schlötelburg C, Wintzingerode C, Hauck R, Wintzingerode F, Hegemann W, Göbel UB (2002) Microbial structure of an anaerobic bioreactor population that continuously dechlorinates 1,2-dichloropropane. FEMS Microbiol Ecol 39:229-237. doi: 10.1111/j.1574-6941.2002.tb00925.x

Sharma PK, McCarty PL (1996) Isolation and characterization of a facultatively aerobic bacterium that reductively dehalogenates tetrachloroethene to cis 1, 2 dichloroethene. Appl Environ Microbio1 $62(3): 761-765$

Sleep BE, Seepersad DJ, Mo K, Heidorn CM, Hrapovic L, Morrill PL, McMaster ML, Hood ED, LeBron C, Sherwood Lollar B, Major DW, Edwards EA (2006) Biological enhancement of tetrachloroethene dissolution and associated microbial community changes. Environ Sci Technol 40(11):3623-3633

Sung Y, Ritalahti KM, Sanford RA, Urbance JW, Flynn SJ, Tiedje JM, Löffler FE (2003) Characterization of two tetrachloroethene-reducing, acetateoxidizing anaerobic bacteria and their description as Desulfuromonas michiganensis sp. nov. Appl Environ Microbiol 69(5):2964-2974

Tiehm A, Schmidt KR (2011) Sequential anaerobic/aerobic biodegradation of chloroethenes-aspects of field application. Curr Opin Biotechnol 22(3):415421

Trevors JT (1996) Sterilization and inhibition of microbial activity in soil. J Microbiol Methods 26(1):53-59

USEPA (1998) Technical protocol for evaluating natural attenuation of chlorinated solvents in ground water. EPA/600/R-98/128. Office of Research and Development. Washington DC 20460 
van der Zaan B, Hannes F, Hoekstra N, Rijnaarts H, de Vos WM, Smidt H, Gerritse J (2010) Correlation of Dehalococcoides 16S rRNA and chloroethene-reductive dehalogenase genes with geochemical conditions in chloroethene-contaminated groundwater. Appl Environ Microbiol 76(3):843850

Verce MF, Gunsch CK, Danko AS, Freedman D (2002) Cometabolism of cis1, 2-dichloroethene by aerobic cultures grown on vinyl chloride as the primary substrate. Environ Sci Technol 36:2171-2177

Vogel TM, MeCarty PL (1985) Biotransformation of tetrachloroethylene to trichloroethylene, dichloroethylene, vinyl chloride, and earbon dioxide under methanogenic conditions. Appl Environ Mierobiol 49(5):1080 1083

Vogel TM, Criddle CS, McCarty PL (1987) ES\&T critical reviews: transformations of halogenated aliphatic compounds. Environ Sci Technol 21(8):722-736

Wei N, Finneran KT (2011) Influence of ferric iron on complete dechlorination of trichloroethylene (TCE) to ethene: Fe (III) reduction does not always inhibit complete dechlorination. Environ Sci Technol 45(17):7422-7430

Wiedemeier TH, Haas PE (2002) Designing monitoring programs to effectively evaluate the performance of natural attenuation. Ground Water Monit Rem 22(3):124-135

Wiedemeier TH, JT Wilson, JE Hansen, FH Chapelle, MA Swanson (1998) Technical protocol for evaluating natural attenuation of chlorinated solvents in groundwater. Air Force Center for Environmental Excellence Brooks AFB TX

Yang YR, McCarty PL (2000) Biologically enhanced dissolution of tetrachloroethene DNAPL. Environ Sci Technol 34(14):2979-2984

Yang YR, McCarty PL (2002) Comparison between donor substrates for biologically enhanced tetrachloroethene DNAPL dissolution. Environ Sci Technol 36(15):3400-3404

Yoshida N, Asahi K, Sakakibara Y, Miyake K, Katayama A (2007) Isolation and quantitative detection of tetrachloroethene (PCE)-dechlorinating bacteria in unsaturated subsurface soils contaminated with chloroethenes. J Biosci 
Bioeng 104(2):91-97

AQ7 